Acta Cryst. (1970). B26, 1089

\title{
The Crystal Structure of Guanosine Dihydrate and Inosine Dihydrate
}

\author{
By Ulf Thewalt, ${ }^{*}$ Charles E. Bugg $\dagger$ and Richard E. Marsh \\ A. A. Noyes Laboratories of Chemical Physics, $\$$ California Institute of Technology, \\ Pasadena, California, U.S.A.
}

(Received 14 August 1969)

\begin{abstract}
Crystals of the dihydrates of guanosine $\left(\mathrm{C}_{10} \mathrm{H}_{13} \mathrm{~N}_{5} \mathrm{O}_{5}\right)$ and inosine $\left(\mathrm{C}_{10} \mathrm{H}_{12} \mathrm{~N}_{4} \mathrm{O}_{5}\right)$ are nearly isostructural. They are monoclinic, space group $P 22_{1}$, with cell dimensions $a=17.518, b=11.502, c=6.658 \AA$, $\beta=98.17^{\circ}$ (guanosine) and $a=17.573, b=11.278, c=6.654 \AA, \beta=98.23^{\circ}$ (inosine). There are two nucleoside molecules and four water molecules per asymmetric unit. Data were collected on an automated diffractometer; the structures were solved by Patterson and trial-and-error methods and refined to $R$ indices of about 0.035 . The structure features hydrogen bonding between purine bases to form ribbons parallel to $\mathbf{b}$ and parallel stacking of purine bases along $\mathbf{c}$; the separation between adjacent rings within a stack is $3 \cdot 3 \AA$. The conformations about the glycosidic $\mathrm{C}-\mathrm{N}$ bond and the puckerings of the sugar rings are quite different for the two molecules in the asymmetric unit.
\end{abstract}

\section{Introduction}

Guanosine (I) and inosine (II) are constituents of the ribonucleic acids (RNA). Guanosine is a major component of most types of RNA; inosine is a minor constituent of the transfer RNA's in which it is believed to occupy the 5 ' terminal position (the 'wobble' position) in a number of the anticodon triplets.

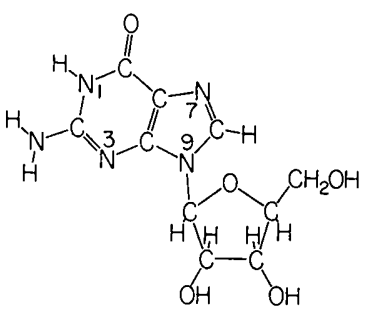

(I)

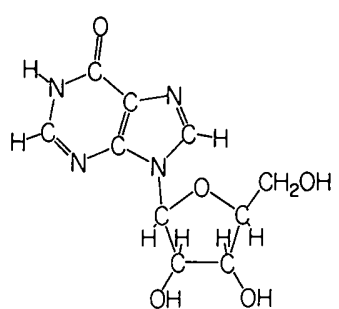

(II)
Several tautomeric forms of the purine ring can be formulated for guanosine and for inosine. Since the possible existence of rare tautomers has important implications regarding base pairing and the corresponding biological properties of the nucleic acids, we felt that the detailed crystal structures of these compounds should be determined. Knowledge of the crystal structures of these nucleosides would also furnish additional information about nucleoside conformation, hydrogen bonding capabilities, and the forces which govern parallel stacking of purine rings in the solid state. We

* Present address: Mineralogisches Institut, Universität Marburg, 335 Marburg/Lahn, Deutschhausstr. 10, West Germany.

$\dagger$ Present address: University of Alabama Medical Center, 1919 Seventh Avenue, South, Birmingham, Alabama 35233, U.S.A.

$\ddagger$ Contribution No. 3884 from the A. A. Noyes Laboratories of Chemical Physics. This investigation was supported in part by Research Grant No. HE-02143 from the United States Publich Health Service. were particularly interested in obtaining structural data which might help explain the mechanism of self association of guanine derivatives in aqueous solution (Gellert, Lipsett \& Davies, 1962; Sarkar \& Yang, 1965; Michelson, 1958), and the unusually stable secondary structures of oligo- and polyguanylic acids (Lipsett, 1964; Pochon \& Michelson, 1965; Radding, Josse \& Kornberg, 1962; Fresco \& Massoulié, 1963; Ralph, Connors, Schaller \& Khorana, 1963).

We report here the crystal structures of guanosine and inosine which demonstrate that these compounds are in their normal tautomer form in the solid state and support the importance of parallel stacking of purine bases as a stabilizing force in the interactions between nucleic acid constituents.

A preliminary report of this work has been published (Bugg, Thewalt \& Marsh, 1968).

\section{Experimental}

Crystals of guanosine, in the form of thin elongated plates, were obtained by slowly cooling a hot saturated solution; inosine was crystallized as thin needles from water by evaporating a saturated solution at room temperature. Crystals of the two compounds were cleaved and fragments were mounted in several different orientations for X-ray study.

Weissenberg and oscillation photographs showed the Laue symmetries to be $C_{2 h}-2 / m$. The space groups $P 2_{1}$ or $P 2_{1} / m$ were indicated for both compounds by the systematic absence of reflections $0 k 0$ with $k$ odd; the space group is necessarily $P 2_{1}$ since the nucleosides are optically active. Similarities in the unit-cell parameters and in the intensity patterns on Weissenberg films indicated that guanosine and inosine are isostructural; this was verified by the subsequent structure determinations.

Accurate values for the unit-cell parameters were obtained from Straumanis-type Weissenberg photo- 
graphs taken about the $b$ and $c$ axes. The positions of a number of high-angle reflections were measured using a travelling microscope and a calibrated steel scale and were included in a least-squares determination of the cell parameters and eccentricity and absorption coefficients. The indicated eccentricity and absorption corrections were insignificantly small. Crystal data, along with the densities measured by flotation, are listed in Table 1.

\begin{tabular}{lcc}
\multicolumn{3}{c}{ Table 1. Crystal data } \\
\multicolumn{3}{c}{$\lambda(\mathrm{Cu} K \alpha)=1.5418 \AA$} \\
Stoichiometry & $\mathrm{C}_{10} \mathrm{H}_{13} \mathrm{~N}_{5} \mathrm{O}_{5} .2 \mathrm{H}_{2} \mathrm{O}$ & $\mathrm{C}_{10} \mathrm{H}_{12} \mathrm{~N}_{4} \mathrm{O}_{5} .2 \mathrm{H}_{2} \mathrm{O}$ \\
Space group & $P 2_{1}$ & $P 2_{1}$ \\
$Z$ & 4 & 4 \\
$a(\AA)$ & $17.518(3)$ & $17.573(1)$ \\
$b$ & $11.502(1)$ & $11 \cdot 278(1)$ \\
$c$ & $6.658(1)$ & $6.654(1)$ \\
$\beta\left(^{\circ}\right)$ & $98.17(3)$ & $98 \cdot 23^{\circ}(1)$ \\
$D_{c}\left({\left.\mathrm{~g} . \mathrm{cm}^{-3}\right)}^{-3}\right)$ & 1.597 & 1.548 \\
$D_{0}\left({\left.\mathrm{~g} . \mathrm{cm}^{-3}\right)}\right.$ & 1.591 & 1.542
\end{tabular}

The guanosine crystal used for collecting intensity data had dimensions $0.2 \times 0.1 \times 0.05 \mathrm{~mm}$; the inosine crystal had dimensions $0.25 \times 0.2 \times 0.1 \mathrm{~mm}$. Intensity data were collected on a Datex-automated, General Electric XRD-5 diffractometer using nickel-filtered copper radiation and a scintillation counter. The intensities were measured using a $\theta-2 \theta$ scanning technique; a scanning speed of $2^{\circ}$ per minute was used for the guanosine measurements, and the inosine measurements were made with a scanning speed of $4^{\circ}$ per minute. Background was counted for 30 seconds for guanosine and 10 seconds for inosine. The scan ranges were adjusted to account for $\alpha_{1}-\alpha_{2}$ splitting. A check reflection was monitored every fifteen reflections. For guanosine, intensity data were collected from two Friedel-related quadrants of the sphere of reflections. In each of the two quadrants, intensity measurements were made for the 2967 reflections in the region between $2 \theta=7^{\circ}$ and $2 \theta=154^{\circ}$. Since the inosine crystal used for the photographic work suffered X-ray damage which especially affected the high-angle reflections, the diffractometer measurements were carried out more rapidly than for guanosine and were confined to the 1431 reflections in the range between $2 \theta=7^{\circ}$ and $2 \theta=100^{\circ}$; only one quadrant from the sphere of reflection was measured. There was no significant fall-off in intensity of the check reflection for either compound.

The measured intensity values were assigned variances, $\sigma^{2}(I)$, according to the statistics of the scan and

Table 2. Final guanosine heavy-atom parameters and their standard deviations

The values have been multiplied by $10^{4}$. The temperature factors are in the form

$$
T=\exp \left(-\beta_{11} h^{2}-\beta_{22} k^{2}-\beta_{33} l^{2}-\beta_{12} h k-\beta_{13} h l-\beta_{23} k l\right) \text {. }
$$

The final value for the extinction parameter $g$ (Laison, 1967) was $6 \cdot 7( \pm 0 \cdot 3) \times 10^{-6}$.

\begin{tabular}{|c|c|c|c|c|c|c|c|c|c|}
\hline Атом & $x$ & y & $z$ & $B_{11}$ & ${ }^{3} 22$ & $B_{33}$ & $\beta_{12}$ & $B_{13}$ & ${ }^{\beta} 23$ \\
\hline \multicolumn{10}{|c|}{ GUANOSINE A } \\
\hline$N(1)$ & $4580(1)$ & $4420(2)$ & $5165(3)$ & $136(6)$ & $292(15)$ & $1440(48)$ & $82(15)$ & $187(27)$ & $21(43)$ \\
\hline$c(2)$ & $3823(1)$ & $4146(2)$ & $5232(3)$ & $157(7)$ & $317(18)$ & $1186(51)$ & $-24(19)$ & $111(30)$ & $17(50)$ \\
\hline $\begin{array}{l}N(2) \\
N(3)\end{array}$ & & $\begin{array}{l}3010(2) \\
4920(2)\end{array}$ & & $\begin{array}{l}185(8) \\
139(6)\end{array}$ & $\begin{array}{l}306(17) \\
284(25)\end{array}$ & $\begin{array}{l}2269(65) \\
1336(49)\end{array}$ & $\begin{array}{r}20(19) \\
-22(15)\end{array}$ & $\begin{array}{l}201(35) \\
157(27)\end{array}$ & $\begin{array}{l}-4(53) \\
62(43)\end{array}$ \\
\hline $\begin{array}{l}8(3) \\
c(4)\end{array}$ & $\begin{array}{l}3267(1) \\
3535(1)\end{array}$ & $\begin{array}{l}4920(2) \\
6021(2)\end{array}$ & $\begin{array}{l}5278(3) \\
5198(3)\end{array}$ & $\begin{array}{l}139(6) \\
137(7)\end{array}$ & $\begin{array}{l}284(15) \\
297(17)\end{array}$ & $1032(50)$ & $\begin{array}{r}-22(15) \\
7(18)\end{array}$ & $126(30)$ & $\begin{array}{l}62(43) \\
17(48)\end{array}$ \\
\hline$c(5)$ & $4278(1)$ & $6384(2)$ & $5127(4)$ & $145(7)$ & $286(17)$ & $1333(57)$ & $3(18)$ & $164(32)$ & $-20(50)$ \\
\hline$c(6)$ & $4868(1)$ & $5542(2)$ & $5082(4)$ & $139(7)$ & $346(18)$ & $1238(50)$ & $-28(19)$ & $95(31)$ & $8(53)$ \\
\hline $0(6)$ & $\begin{array}{l}5556(1) \\
436(1)\end{array}$ & $5715(2)$ & $\begin{array}{l}4970(3) \\
5043(3)\end{array}$ & $124(5)$ & $488(16)$ & $2245(51)$ & $12(15)$ & $284(26)$ & $46(45)$ \\
\hline N(7) & $4316(1)$ & $7589(2)$ & $5043(3)$ & $156(7)$ & $280(15)$ & $1636(54)$ & $-65(16)$ & $212(30)$ & $2(45)$ \\
\hline $\begin{array}{l}\mathrm{C}(8) \\
\mathrm{N}(9)\end{array}$ & $\begin{array}{l}3608(1) \\
307(1)\end{array}$ & $7928(2)$ & $5044(4)$ & $\begin{array}{l}188(8) \\
152(5)\end{array}$ & $\begin{array}{l}271(18) \\
265(15)\end{array}$ & $1536(60)$ & $-27(20)$ & $197(34)$ & $11(53)$ \\
\hline $\begin{array}{l}x(9), \\
c(1) \text {, }\end{array}$ & $\begin{array}{l}3097(1) \\
2269(1)\end{array}$ & $\begin{array}{l}7020(2) \\
7079(2)\end{array}$ & $\begin{array}{l}5126(3) \\
5151(4)\end{array}$ & $152(6)$ & $\begin{array}{l}266(15) \\
315(1)\end{array}$ & $\begin{array}{l}1204(45) \\
1154(52)\end{array}$ & $51(16)$ & $148(25)$ & $10(43)$ \\
\hline o(1) & $1896(1)$ & $\begin{array}{l}7799(2) \\
6433(1)\end{array}$ & $3490(2)$ & $\begin{array}{l}141(7) \\
183(6)\end{array}$ & $\begin{array}{l}316(18) \\
333(13)\end{array}$ & $\begin{array}{l}1154(52) \\
1303(4)\end{array}$ & $\begin{array}{l}-4(18) \\
66(14)\end{array}$ & $174(29)$ & $12(50)$ \\
\hline c(2)! & $1950(1)$ & $8314(2)$ & $4870(4)$ & $153(7)$ & $\begin{array}{l}333(13) \\
287(17)\end{array}$ & $\begin{array}{l}1303(4) \\
1287(56)\end{array}$ & $\begin{array}{l}66(14) \\
35(19)\end{array}$ & $\begin{array}{l}-32(23) \\
210(32)\end{array}$ & $\begin{array}{l}220(37) \\
-23(50)\end{array}$ \\
\hline $0(2)^{\prime}$ & $2037(\mathrm{I})$ & $8991(2)$ & $6656(3)$ & $222(6)$ & $332(14)$ & $1373(43)$ & $-43(15)$ & $294(25)$ & $\begin{array}{l}-23(50) \\
313(40)\end{array}$ \\
\hline c(3)! & $1119(1)$ & $8092(2)$ & $3936(4)$ & $154(8)$ & $379(19)$ & $1420(57)$ & $38(19)$ & $281(33)$ & $85(54)$ \\
\hline $0(3)^{\prime}$ & $651(1)$ & $7821(2)$ & $5454(3)$ & $185(6)$ & $538(16)$ & $1951(49)$ & $-99(17)$ & $643(27)$ & $441(48)$ \\
\hline$c(4) !$ & $1183(1)$ & $6997(2)$ & $2659(4)$ & $124(7)$ & $425(20)$ & $1441(57)$ & $16(20)$ & $126(30)$ & $74(56)$ \\
\hline$c(s) !$ & 1209 (1) & $7195(3)$ & $0424(4)$ & $183(8)$ & $568(23)$ & $1412(60)$ & $47(23)$ & $80(35)$ & $21(63)$ \\
\hline$O(s)^{\prime}$ & $1903(1)$ & $7755(2)$ & $0074(3)$ & $237(7)$ & $507(16)$ & $1586(44)$ & $23(17)$ & $426(27)$ & $292(44)$ \\
\hline \multicolumn{10}{|c|}{ GUANOSINE B } \\
\hline $\mathbb{N}(1)$ & $4606(1)$ & $6890(1)$ & $10100(3)$ & $137(6)$ & $313(16)$ & $1547(51)$ & $-49(16)$ & $243(28)$ & $-17(45)$ \\
\hline $\begin{array}{l}c(2) \\
N(2)\end{array}$ & $\begin{array}{l}3850(1) \\
3681(1)\end{array}$ & $7175(2)$ & $10126(3)$ & $149(7)$ & $\begin{array}{l}320(18) \\
258(16)\end{array}$ & $\begin{array}{l}1128(52) \\
218963)\end{array}$ & $-41(19)$ & $179(30)$ & $65(50)$ \\
\hline $\begin{array}{l}N(2) \\
N(3)\end{array}$ & $\begin{array}{l}3681(1) \\
3291(1)\end{array}$ & $\begin{array}{l}8317(2) \\
6402(2)\end{array}$ & $\begin{array}{l}10030(4) \\
10213(3)\end{array}$ & $\begin{array}{l}176(7) \\
128(6)\end{array}$ & $\begin{array}{l}258(16) \\
293(14)\end{array}$ & $\begin{array}{l}2189(63) \\
1326(47)\end{array}$ & $1(18)$ & $280(33)$ & $8(50)$ \\
\hline $\begin{array}{l}N(3) \\
c(4)\end{array}$ & $\begin{array}{l}3291(1) \\
3559(1)\end{array}$ & $5290(2)$ & $\begin{array}{l}\begin{array}{l}102133(3) \\
10240(3)\end{array} \\
\text { (2) }\end{array}$ & $145(7)$ & $\begin{array}{l}293(14) \\
327(18)\end{array}$ & $\begin{array}{l}1326(47) \\
1086(51)\end{array}$ & $\begin{array}{r}00(15) \\
-54(18)\end{array}$ & $\begin{array}{l}194(26) \\
127(30)\end{array}$ & $\begin{array}{r}-47(43) \\
6(49)\end{array}$ \\
\hline c(5) & $4306(1)$ & $4923(2)$ & $10182(3)$ & $159(7)$ & $296(17)$ & $1144(53)$ & $41(18)$ & $202(31)$ & $24(46)$ \\
\hline$c(6)$ & $4894(1)$ & $5763(2)$ & $10103(4)$ & $166(8)$ & $375(20)$ & $1130(50)$ & $-18(19)$ & $184(31)$ & $-41(51)$ \\
\hline $0(6)$ & $5587(1)$ & $5593(2)$ & $10032(3)$ & $134(5)$ & $449(15)$ & $2270(51)$ & $-11(15)$ & $367(26)$ & $-67(46)$ \\
\hline$N(7)$ & $4348(1)$ & $3721(2)$ & $10194(3)$ & $159(7)$ & $316(15)$ & $1594(52)$ & $15(17)$ & $201(29)$ & $65(45)$ \\
\hline c(8) & $3637(1)$ & $3386(2)$ & $10258(4)$ & $176(8)$ & $282(18)$ & $1800(66)$ & $-2\langle 20\rangle$ & $285(34)$ & $-39(56)$ \\
\hline N(9) & $3136(1)$ & $4291(2)$ & $10306(3)$ & $138(6)$ & $298(15)$ & $1480(48)$ & $-17(16)$ & $230(27)$ & $32(44)$ \\
\hline$c(1) !$ & 2309 (1) & $4202(2)$ & $10310(4)$ & $137(7)$ & $304(18)$ & $1677(59)$ & $-68(19)$ & $320(32)$ & $50(54)$ \\
\hline$O(1) !$ & $\begin{array}{l}2174(1) \\
1859(1)\end{array}$ & $3353(2)$ & $\begin{array}{l}11750(3) \\
8335(4)\end{array}$ & $176(6)$ & $544(16)$ & $1462(43)$ & $-197(16)$ & $168(24)$ & $298(43)$ \\
\hline$c(2) !$ & $\begin{array}{l}1859(1) \\
1737(1)\end{array}$ & $3756(2)$ & $\begin{array}{l}8335(4) \\
6768(3)\end{array}$ & $\begin{array}{l}153(7) \\
192(6)\end{array}$ & $445(20)$ & $\begin{array}{l}1507(58) \\
1959(5))\end{array}$ & $\begin{array}{l}-23(20) \\
12019)\end{array}$ & $\begin{array}{l}320(33) \\
355(29)\end{array}$ & $104(57)$ \\
\hline $\begin{array}{l}O(2)\} \\
c(3),\end{array}$ & $\begin{array}{l}1737(1) \\
1102(1)\end{array}$ & $\begin{array}{l}4578(2) \\
3390(2)\end{array}$ & $\begin{array}{l}6768(3) \\
9067(4)\end{array}$ & $\begin{array}{l}192(6) \\
151(8)\end{array}$ & $\begin{array}{l}877(21) \\
462(21)\end{array}$ & $\begin{array}{l}1996(51) \\
1743(65)\end{array}$ & $\begin{array}{r}12(19) \\
-97(21)\end{array}$ & $\begin{array}{l}355(29) \\
227(35)\end{array}$ & $\begin{array}{l}1023(54) \\
-10961)\end{array}$ \\
\hline $\begin{array}{l}\text { c(3), } \\
0(3)\end{array}$ & $\begin{array}{l}1102(1) \\
600(1)\end{array}$ & $\begin{array}{l}3390(2) \\
4355(2)\end{array}$ & $\begin{array}{l}9067(4) \\
9144(3)\end{array}$ & $\begin{array}{l}151(8) \\
161(6)\end{array}$ & $\begin{array}{l}4622(21) \\
684(19)\end{array}$ & $\begin{array}{l}1743(65) \\
1867(51)\end{array}$ & $\begin{array}{l}-97(21) \\
116(17)\end{array}$ & $\begin{array}{l}227(35) \\
313(27)\end{array}$ & $\begin{array}{r}-109(61) \\
429(50)\end{array}$ \\
\hline$c(4)^{\prime}$ & $1373(1)$ & $2993(2)$ & $21244(4)$ & $163(8)$ & $525(23)$ & $1653(63)$ & $-72(21)$ & $344(35)$ & $\begin{array}{l}429(50) \\
167(61)\end{array}$ \\
\hline$c(5)^{\prime}$ & $1321(2)$ & $1699(3)$ & $11606(5)$ & $217(10)$ & $637(27)$ & $2652(92)$ & $-184(25)$ & $330(46)$ & $712(79)$ \\
\hline$o(s)^{\prime}$ & $1619(1)$ & $1031(2)$ & $10101(4)$ & $258(8)$ & $563(18)$ & $3463(74)$ & $7(20)$ & $-44(38)$ & $-343(61)$ \\
\hline \multicolumn{10}{|l|}{ MAIER } \\
\hline$O(10)$ & $7073(2)$ & $5945(2)$ & $3612(5)$ & $325(10)$ & $700(23)$ & $4618(102)$ & $289(25)$ & $668(52)$ & $-1050(77)$ \\
\hline o(11) & $6947(1)$ & $\$ 510(2)$ & $7962(5)$ & $230(8)$ & $779(23)$ & $3090(81)$ & $-115(22)$ & & $169(73)$ \\
\hline$o(12)$ & $9983(1)$ & $5612(2)$ & $5896(4)$ & $360(9)$ & $709(22)$ & $1964(58)$ & $-97(23)$ & $477(56)$ & $313(59)$ \\
\hline $0(13)$ & $9573(1)$ & $4722(2)$ & $1970(3)$ & $233(7)$ & $649(19)$ & $1829(51)$ & $36(19)$ & $328(31)$ & $186(51)$ \\
\hline
\end{tabular}


background counts but including an extra term $(0.02 S)^{2}, S$ being the scan counts. For guanosine, the measurements from the two quadrants were averaged and the appropriate standard deviations for the averages were calculated. Finally, the intensities and their standard deviations were corrected for Lorentz and polarization factors and placed on an approximately absolute scale by means of Wilson plots.

\section{The trial structure}

The structure of guanosine was solved first. A sharpened three-dimensional Patterson map had major features in the two sections $w=0$ and $w=0 \cdot 5$, suggesting that the planar purine rings are approximately parallel to the (001) plane and are separated by $c / 2$. We utilized only these two sections in initial efforts to obtain trial coordinates.

The vector set expected for the 9-methylguanine moiety was plotted on tracing paper and rotated about the origin of the Patterson map; only one orientation (plus the three other orientations related by the $2 / m$ symmetry of the Patterson map) satisfactorily explained the observed features, suggesting that the two crystallographically-independent bases have related orientations.

On the basis of packing considerations, we quickly settled on a model in which the two crystallographically-independent purine rings were hydrogen bonded together across a pseudo center of symmetry. [A center of symmetry had been strongly indicated by a Howells, Phillips \& Rogers (1950) plot.] This model required that

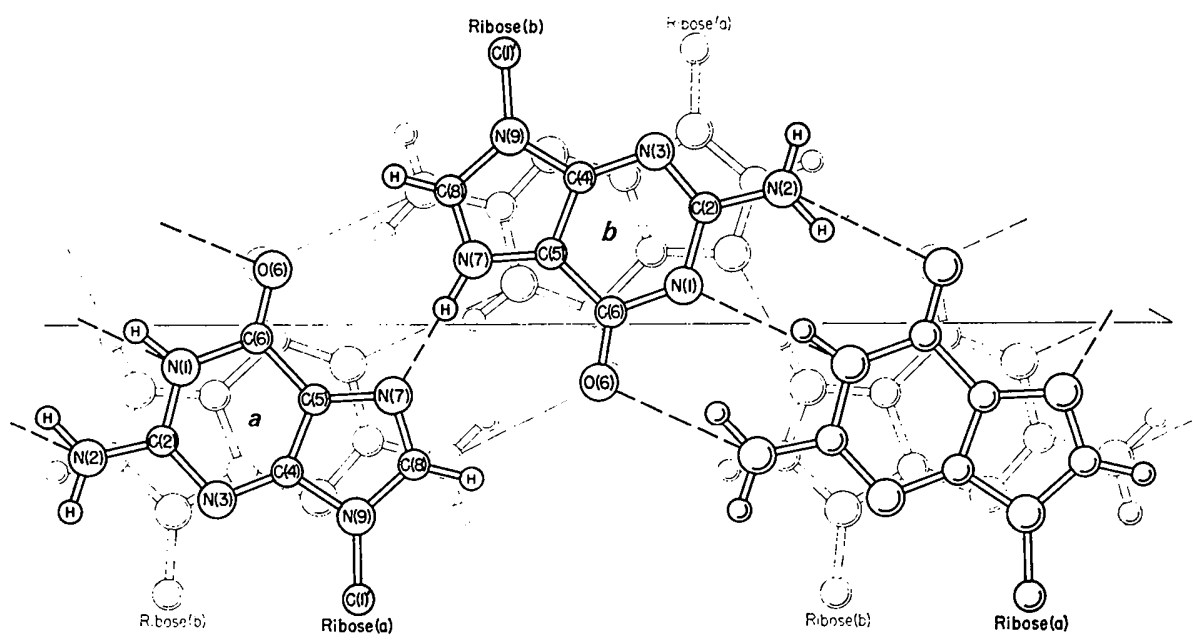

(a)

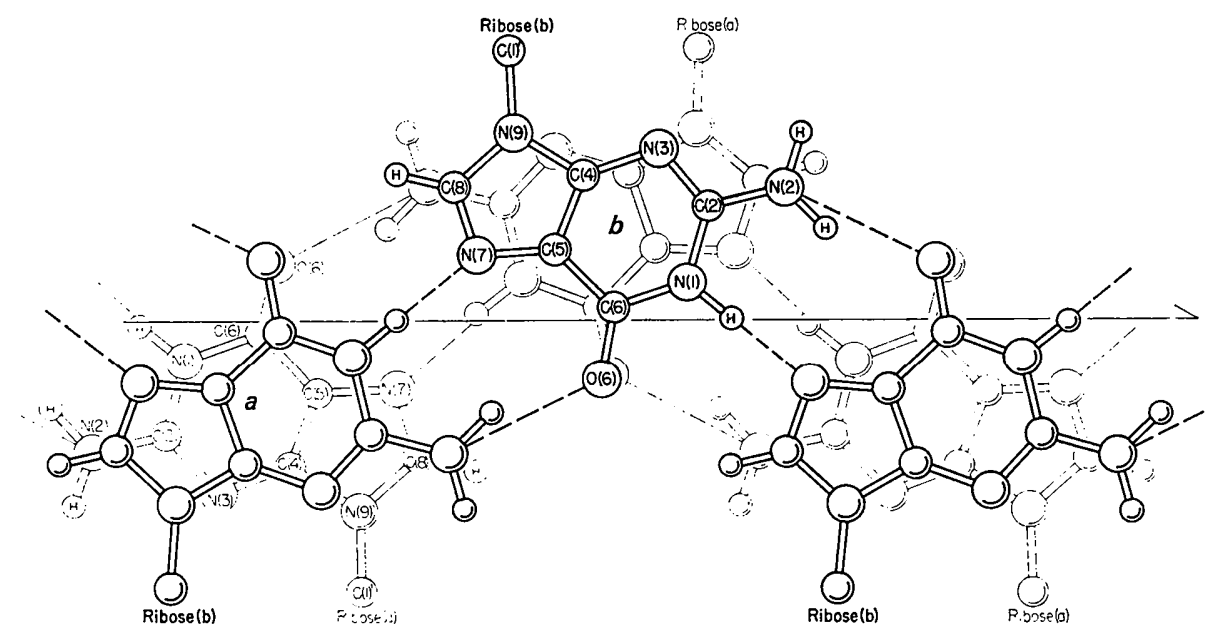

(b)

Fig. 1. Possible models for hydrogen bonding between guanine bases as determined from the $c$ axis projection. $(a)$ incorrect model, (b) correct structure. 
two different tautomers be present in the crystal structure: the usual one shown in (I) and a second, zwitterionic tautomer in which $\mathrm{N}(7)$ rather than $\mathrm{N}(1)$ is protonated. In this proposed structure [Fig. 1(a)], the two independent bases lie at $z=0.25$ and are joined by three hydrogen bonds. Approximate $x$ coordinates for the atoms of this base pair were obtained from the $W=0.5$ section of the Patterson map; since the space group is polar, the location of the dimer in the b direction is arbitrary.

Efforts to locate the ribose atoms from three-dimensional Fourier syntheses phased with the trial coordinates for the guanine atoms were unsuccessful. We then concentrated on the $h k 0$ data, for although the purine rings were closely superimposed when projected down $\mathrm{c}$ we anticipated that the sugar rings would be resolved. We wrote a computer program to examine the $R$ index $\left(=\sum|| F_{o}|-| F_{c}|| / \sum F_{o} \mid\right)$ for the 260 lowangle $h k 0$ reflections as a function of the orientations of the sugar rings about the glycosidic $\left[C\left(1^{\prime}\right)-N(9)\right]$ bonds; the assumed geometry of the sugar rings themselves was that reported for cytidylic acid $b^{\prime}$ (Bugg \& Marsh, 1967), atom $\mathrm{O}\left(5^{\prime}\right)$ being excluded. The atoms of one ribose ring (nucleoside $A$ ) were easily located by this method, a plot of the $R$ index against the angle of rotation around the glycosidic bond showing a pronounced minimum at $R=0 \cdot 50$.
Table 3. Final guanosine hydrogen atom parameters and their estimated standard deviations (positional parameters $\times 10^{3}$ )

\begin{tabular}{|c|c|c|c|c|}
\hline ATOM & $\mathbf{x}$ & y & $z$ & $B\left(\dot{A}^{2}\right)$ \\
\hline \multicolumn{5}{|c|}{ GUABOSZNE A } \\
\hline $\begin{array}{l}\mathrm{H}(1) \\
\mathrm{H}(2) \\
\mathrm{H}(3) \\
\mathrm{B}(4) \\
\mathrm{H}(5) \\
\mathrm{H}(6) \\
\mathrm{H}(7) \\
\mathrm{H}(8) \\
\mathrm{B}(9) \\
\mathrm{H}(10) \\
\mathrm{H}(11) \\
\mathrm{H}(12) \\
\mathrm{H}(13)\end{array}$ & $\begin{array}{r}217(1) \\
219(1) \\
87(1) \\
75(1) \\
191(2) \\
63(2) \\
77(2) \\
114(2) \\
234(2) \\
344(1) \\
494(2) \\
405(2) \\
317(2)\end{array}$ & $\begin{array}{l}672(2) \\
872(2) \\
878(3) \\
643(2) \\
869(4) \\
850(3) \\
761(3) \\
637(3) \\
716(4) \\
872(2) \\
382(3) \\
247(3) \\
286(3)\end{array}$ & $\begin{array}{r}644(3) \\
390(4) \\
306(4) \\
283(4) \\
763(6) \\
617(4) \\
-9(4) \\
-30(4) \\
26(7) \\
504(4) \\
512(3) \\
525(4) \\
512(4)\end{array}$ & $\begin{array}{l}1.0(.4) \\
1.9(.5) \\
3.0(.6) \\
1.8(.5) \\
7.0(1.2) \\
4.0(7) \\
3.8(.7) \\
3.3(.7) \\
8.9(1.3) \\
2.7(.6) \\
4.2(.7) \\
3.7(.7) \\
3.7(.7)\end{array}$ \\
\hline \multicolumn{5}{|c|}{ GUANOSINE B } \\
\hline $\begin{array}{l}\mathrm{H}(1) \\
\mathrm{H}(2) \\
\mathrm{H}(3) \\
\mathrm{H}(4) \\
\mathrm{H}(5) \\
\mathrm{B}(6) \\
\mathrm{B}(7) \\
\mathrm{H}(8) \\
\mathrm{H}(9) \\
\mathrm{H}(10) \\
\mathrm{H}(11) \\
\mathrm{H}(12) \\
\mathrm{H}(13)\end{array}$ & $\begin{array}{r}215(1) \\
215(1) \\
88(1) \\
106(2) \\
220(2) \\
47(2) \\
154(2) \\
76(2) \\
214(2) \\
351(1) \\
494(2) \\
408(2) \\
321(2)\end{array}$ & $\begin{array}{l}498(2) \\
301(3) \\
276(2) \\
345(3) \\
464(3) \\
472(3) \\
149(3) \\
153(2) \\
74(4) \\
256(2) \\
743(3) \\
893(3) \\
856(3)\end{array}$ & $\begin{array}{r}1069(4) \\
790(4) \\
825(4) \\
1217(4) \\
634(5) \\
800(5) \\
1297(5) \\
1146(4) \\
1064(6) \\
1025(4) \\
996(5) \\
1001(4) \\
1029(4)\end{array}$ & $\begin{array}{l}2.0(.5) \\
3.1(.6) \\
2.3(.5) \\
3.4(6) \\
6.1(1.0) \\
5.3(1.0) \\
4.5(.8) \\
3.4(.7) \\
7.3(1.1) \\
3.1(.6) \\
3.3(.7) \\
4.2(7) \\
3.2(.6)\end{array}$ \\
\hline \multicolumn{5}{|l|}{ KASTER } \\
\hline $\begin{array}{l}H(10) \\
H(10)^{\prime} \\
H(11) \\
H(11)^{\prime} \\
H(12), \\
H(12)^{\prime} \\
H(13), \\
H(13),\end{array}$ & $\begin{array}{r}735(2) \\
659(3) \\
698(2) \\
644(2) \\
1022(2) \\
989(2) \\
992(2) \\
916(2)\end{array}$ & $\begin{array}{l}540(3) \\
600(5) \\
567(4) \\
565(4) \\
631(4) \\
541(4) \\
472(4) \\
511(3)\end{array}$ & $\begin{array}{l}320(5) \\
292(7) \\
681(7) \\
808(6) \\
578(6) \\
455(8) \\
115(5)\end{array}$ & $\begin{array}{r}4.8(.9) \\
11.0(1.7) \\
7.9(1.5) \\
7.8(1.2) \\
6.3(1.1) \\
8.9(1.4) \\
6.1(1.0)\end{array}$ \\
\hline $\mathrm{H}(13)^{\prime}$ & $916(2)$ & $511(3)$ & $241(5)$ & $4.6(.9)$ \\
\hline
\end{tabular}

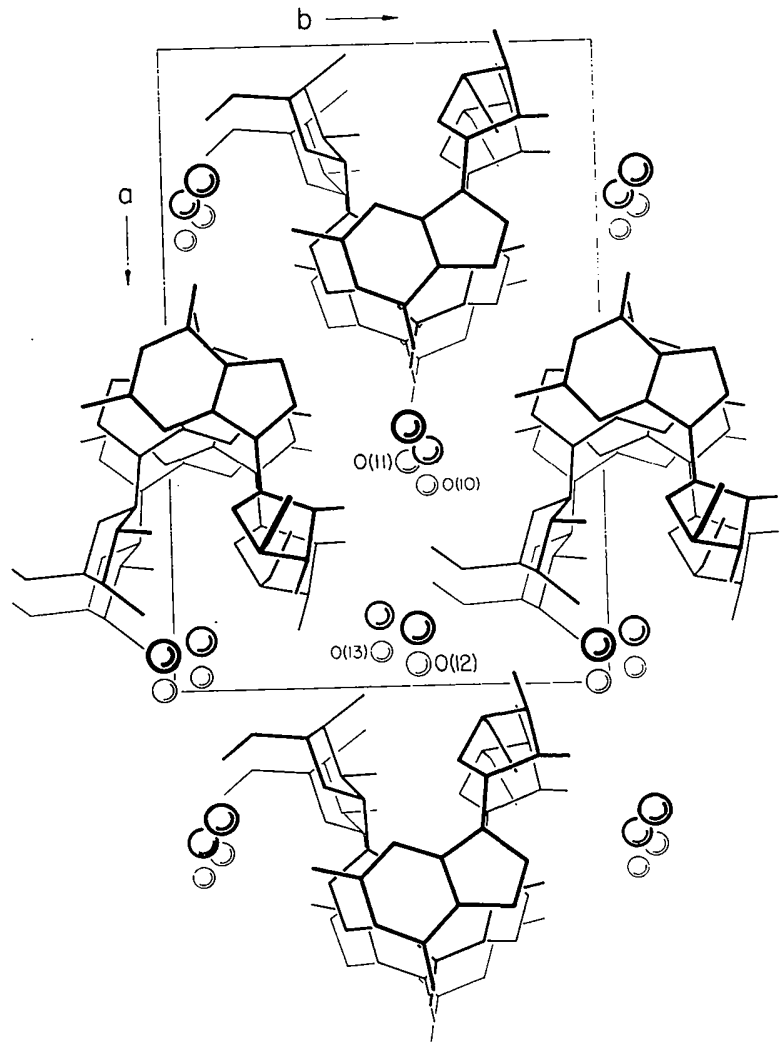

Fig. 2. The guanosine structure viewed down the $c^{*}$ direction.

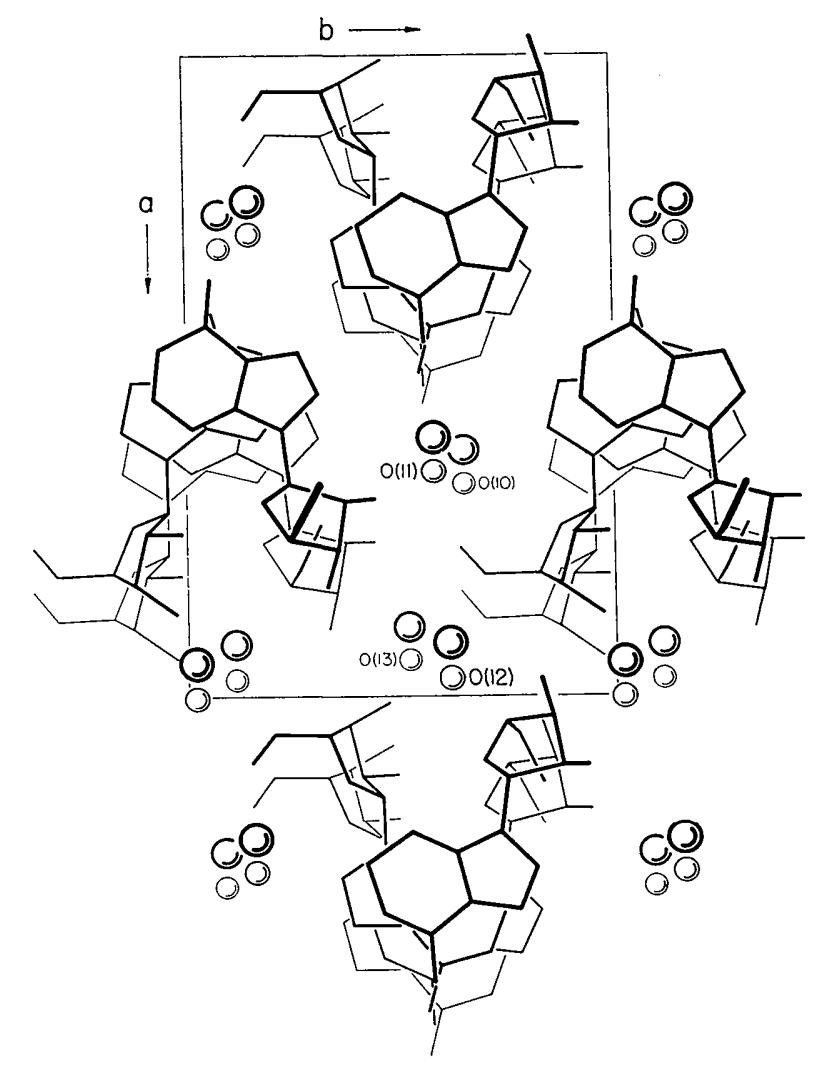

Fig. 3. The inosine structure viewed down the $c^{*}$ direction. 
Table 4. Observed and calculated structure factors for guanosine

From left to right, the columns contain values of $h, 10 F_{o}, 10 F_{c}$, and $\alpha$, the phase angle (in degrees). A blank value for $10 F_{o}$ signifies that the integrated intensity was below background level.

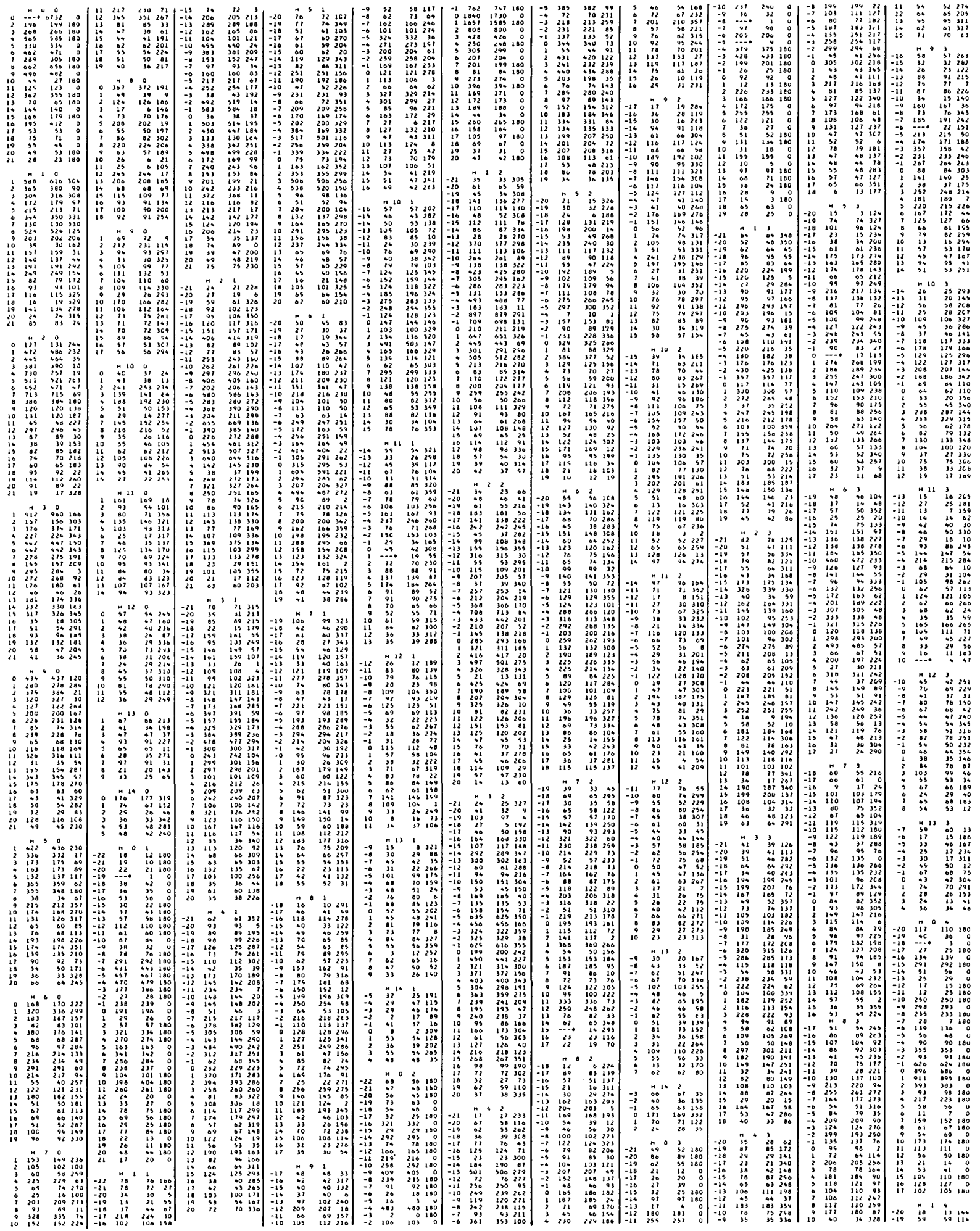


Table 4 (cont.)
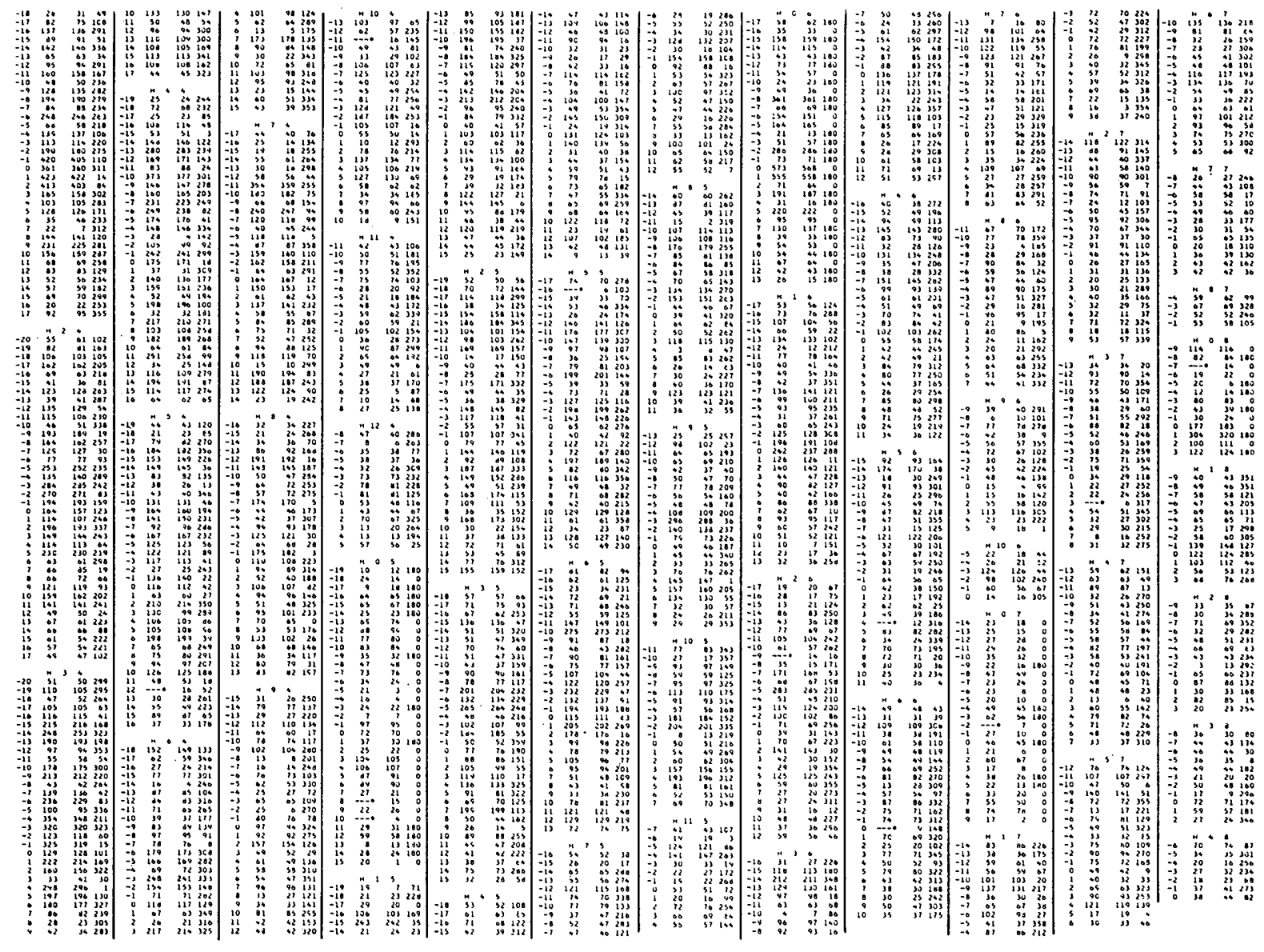

The results obtained by rotating the other ribose moiety (nucleoside $B$ ) were ambiguous; in retrospect, the difficulty was due to small errors in the positions of atoms $C\left(1^{\prime}\right)$ and $N(9)$ and to differences between the conformations of this ribose ring and the ribose ring of cytidylic acid. The coordinates of the atoms of the two purine rings and of the ribose ring of nucleoside $A$ were improved by the use of difference electron density projections, whereupon rotation of the ribose ring of nucleoside $B$ resulted in a minimum at $R=0 \cdot 38$. Finally, the water oxygen atoms and atoms $\mathrm{O}\left(5^{\prime}\right)$ of the ribose moieties were located from difference maps and the projection trial structure was refined by Fourier techniques to $R=0 \cdot 22$.

The only remaining task appeared to be the assignment of suitable $z$ coordinates to the atoms of the sugar rings. However, many attempts - including trial-anderror, Fourier, and least-squares calculations based on the $h 0 l$ reflections and low-angle three-dimensional data - were unsuccessful. We eventually noted that agreement between $F_{\text {obs }}$ and $F_{\text {cal }}$ was consistently better for reflections with $l$ even than for those with $l$ odd; we also noted that shifts of 0.25 in the $z$ coordinates of the atoms of the purine rings resulted in an entirely different but eminently reasonable hydrogen bonding arrangement. After shifting the $z$ coordinates, we immediately found a complete three-dimensional trial structure $(R=0 \cdot 35)$.

The correct arrangement of purine rings is shown in Fig. 1(b). In this arrangement the two crystallographically-independent bases form separate hydrogen-bonded ribbons, each ribbon lying on a $2_{1}$ axis. In the original, incorrect model [Fig. 1(a)], on the other hand, both kinds of bases are contained in a single ribbon and the $2_{1}$ axes lie midway between successive ribbons. We find it a bit surprising that two hydrogen-bonded arrangements of bases, each reasonable but so fundamentally different from one another, should have such a simple structural relationship.

\section{Refinement of the structures}

Three-dimensional refinement of the trial structures was carried out mainly by least-squares. The quantity minimized was $\sum w\left(F_{o}^{2}-\frac{1}{k^{2}} F_{c}^{2}\right)^{2}$. Each reflection was 
assigned a weight $w$ equal to $1 / \sigma^{2}\left(F_{o}^{2}\right)$ except for those with measured intensities below the background level, which were assigned weights of zero. Atomic scattering factors for the non-hydrogen atoms were obtained from International Tables for X-ray Crystallography (1962), and those for the hydrogen atoms were from Stewart, Davidson \& Simpson (1965).

The structure of guanosine was completely refined before any attempt was made to refine the inosine structure. The heavy-atom positional parameters and isotropic temperature factors were refined by fullmatrix least squares to an $R$ index of $0 \cdot 18$. At this point, the heavy atoms were assigned anisotropic temperature factors, and during all additional refinements, the anisotropic temperature parameters were varied along with the positional parameters. Because of the limited core storage size of the computer, full-matrix refinement of all these parameters was not practicable; therefore, various combinations of parameters were distributed among several full matrices. In this manner the heavy atom parameters were adjusted to give an $R$ index of 0.08 . A difference map was then calculated, from which the positional parameters for all but four of the 34 hydrogen atoms were readily determined. Several additional least-squares cycles reduced the $R$

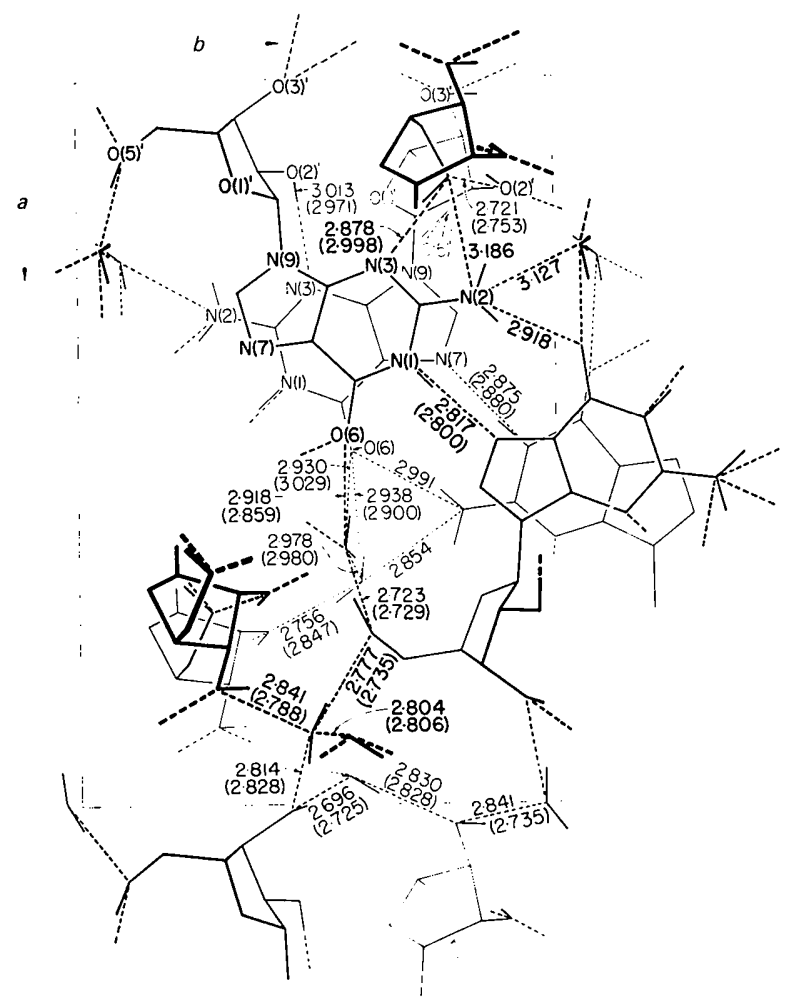

Fig. 4. Hydrogen bonding in guanosine and inosine as viewed down the $c^{*}$ axis. The dashed lines represent hydrogen bonds. The numbers in parentheses represent the hydrogen bond lengths for inosine; other lengths correspond to guanosine. (Inosine lacks the amino group.) index to $0 \cdot 06$, at which stage the remaining hydrogen atoms were located. The refinement was completed with several cycles of multiple-matrix refinement during which all the positional parameters, anisotropic temperature parameters for the heavy atoms, and isotropic temperature factors for the hydrogen atoms were adjusted, together with the scale factor and an extinction parameter (Larson, 1967).

The final $R$ index for the 2946 reflections of non-zero weight is 0.036 . In the last cycle of refinement, no parameter shift exceeded one-fifth of its indicated standard deviation. The final 'goodness of fit', $\left[\sum w\left(F_{o}^{2}-F_{c}^{2} / k^{2}\right)^{2} /(m-s)\right]^{1 / 2}$, is $1 \cdot 5$. The average estimated standard deviations in the final positional coordinates are $0.002-0.003 \AA$ for the $\mathrm{C}, \mathrm{N}$, and $\mathrm{O}$ atoms and about $0.03 \AA$ for the $\mathrm{H}$ atom, corresponding to e.s.d.'s of about $0.004 \AA$ for bond lengths involving only heavy atoms, $0.03 \AA$ for bonds involving hydrogen atoms, and about $0.5^{\circ}$ for bond angles. In view of the good agreement for the bond lengths and angles in the crystallographically independent guanosine molecules, these estimated errors appear to be reasonable. At the conclusion of the refinement, a three-dimensional electron-density difference map was calculated; this map showed no peaks or troughs exceeding $0.25 \mathrm{e} . \AA^{-3}$ in magnitude.

The final heavy-atom parameters and their estimated standard deviations are listed in Table 2; the hydrogen atom parameters and their estimated standard deviations are listed in Table 3. Observed and calculated structure factors are given in Table 4.

Multiple-matrix least-squares refinement of the inosine structure was initiated using the atomic parameters found for guanosine (excluding the amino groups). During the latter stages of this refinement, all the positional parameters of the heavy atoms were included in one matrix, and the near-singularity of the matrix was removed by holding the $y$ parameter of atom $\mathrm{N}(9)$ fixed. In the last cycle of refinement, no parameter shift exceeded one-fifth of its standard deviation. The final $R$ index was 0.032 for the 1423 non-zero-weight reflections; the final 'goodness-of-fit' was $1 \cdot 7$. The average estimated standard deviations in the final positional parameters are $\mathrm{O}=0.004, \mathrm{~N}=0.004, \mathrm{C}=$ 0.005 , and $\mathrm{H}=0.05 \AA$; these standard deviations are larger than those for guanosine because only lowangle data $\left(2 \theta \leq 100^{\circ}\right)$ were collected for inosine. The standard deviations in the bond lengths are approximately $0.006 \AA$ for bonds between heavy atoms and $0.05 \AA$ for bond lengths involving hydrogen atoms; the e.s.d.'s in the bond angles are about $0.5^{\circ}$.

The heavy atom parameters and standard deviations for inosine are shown in Table 5, and the hydrogenatom parameters and standard deviations are listed in Table 6. Observed and calculated structure factors are given in Table 7. A three-dimensional electron-density difference map calculated at the conclusion of the refinement showed no peaks or troughs exceeding $0 \cdot 15$ e. $\AA^{-3}$ in magnitude. 
Table 5. Final inosine heavy-atom parameters and their standard deviations.

The values have been multiplied by $10^{4}$. The temperature factors are in the form

$$
T=\exp \left(-\beta_{11} h^{2}-\beta_{22} k^{2}-\beta_{33} l^{2}-\beta_{12} h k-\beta_{13} h l-\beta_{23} k l\right) \text {. }
$$

The final value for the extinction parameter $g$ was $28 \cdot 0( \pm 0 \cdot 7) \times 10^{-6}$.

\begin{tabular}{|c|c|c|c|c|c|c|c|c|c|}
\hline Aтон & $x$ & $y$ & 2 & $\beta_{11}$ & $B_{22}$ & $B_{33}$ & $B_{12}$ & $B_{13}$ & $\beta_{23}$ \\
\hline \multicolumn{10}{|c|}{ INOSINE A } \\
\hline$N(1)$ & $4447(2)$ & $4449(4)$ & $5180(6)$ & $169(17)$ & $430(36)$ & $1343(122)$ & $56(43)$ & $181(70)$ & $-52(114)$ \\
\hline c(2) & $3687(3)$ & $4302(4)$ & $5314(8)$ & $270(24)$ & $363(43)$ & $1225(144)$ & $-37(52)$ & $187(90)$ & $-24(138)$ \\
\hline N(3) & $3181(2)$ & $5148(3)$ & $5361(6)$ & $191(15)$ & $385(34)$ & $1103(117)$ & $-24(39)$ & $208(69)$ & $-11(108)$ \\
\hline$c(4)$ & $3503(2)$ & $6235(4)$ & $5185(7)$ & $181(19)$ & $296(39)$ & $926(129)$ & $24(49)$ & $145(78)$ & $27(129)$ \\
\hline$c(5)$ & $4264(3)$ & $6493(4)$ & $5061(7)$ & $169(20)$ & $450(45)$ & $832(134)$ & $51(45)$ & $97(83)$ & $-36(125)$ \\
\hline$c(6)$ & $4804(3)$ & $5549(4)$ & $5015(8)$ & $208(22)$ & $541(44)$ & $1110(136)$ & $61(53)$ & $-9(95)$ & $-5(138)$ \\
\hline $0(6)$ & $5486(2)$ & $5617(3)$ & $4861(5)$ & $133(14)$ & $770(33)$ & $2505(121)$ & $44(35)$ & $476(65)$ & $176(110)$ \\
\hline $\begin{array}{l}N(7) \\
C(8)\end{array}$ & $4368(2)$ & $7694(3)$ & $4916(6)$ & $159(16)$ & $430(38)$ & $1840(134)$ & $-21(41)$ & $134(74)$ & $131(113)$ \\
\hline $\begin{array}{l}c(8) \\
\forall(9)\end{array}$ & $\begin{array}{l}3682(2) \\
33133(2)\end{array}$ & $8142(5)$ & $\begin{array}{l}4953(8) \\
5093(6)\end{array}$ & $\begin{array}{l}219(23) \\
116(15)\end{array}$ & $\begin{array}{l}440(47) \\
413(34)\end{array}$ & $1567(161)$ & $-45(56)$ & $287(95)$ & $\begin{array}{l}-39(147) \\
6(111)\end{array}$ \\
\hline , & $\begin{array}{l}3308(2) \\
2308(2)\end{array}$ & $\begin{array}{l}7309 \\
7472(4)\end{array}$ & $\begin{array}{l}5093(6) \\
5104(8)\end{array}$ & $\begin{array}{l}136(15) \\
133(17)\end{array}$ & $\begin{array}{l}413(34) \\
424(39)\end{array}$ & $\begin{array}{l}1129(114) \\
1055(144)\end{array}$ & $\begin{array}{l}-59(41) \\
18(45)\end{array}$ & $\begin{array}{l}156(68) \\
279(85)\end{array}$ & $\begin{array}{r}67(1111) \\
-34(143)\end{array}$ \\
\hline c(1) & 1917 (2) & $6841(3)$ & $3426(5)$ & $213(13)$ & $434(28)$ & $1307(96)$ & $\begin{array}{l}18(45) \\
67(33)\end{array}$ & $\begin{array}{l}279(85) \\
-71(58)\end{array}$ & $\begin{array}{l}-34(143) \\
-106(95)\end{array}$ \\
\hline$c(2)$ ' & $2047(3)$ & $8755(4)$ & $4775(8)$ & $186(20)$ & $452(41)$ & $1182(145)$ & $28(48)$ & $313(88)$ & $\begin{array}{l}-106(95) \\
-138(146)\end{array}$ \\
\hline o(2)! & $2180(2)$ & $9464(3)$ & $6549(6)$ & $280(15)$ & $486(31)$ & $1360(111)$ & $-46(36)$ & $366(68)$ & $-313(118)$ \\
\hline$c(3)^{\prime}$ & $1210(3)$ & $8592(4)$ & $3878(8)$ & $165\langle 20\}$ & $477(47)$ & $1664(157)$ & $83(51)$ & $242(97)$ & $240(157)$ \\
\hline $0(3) !$ & $741(2)$ & $8334(3)$ & $5389(6)$ & $219(14)$ & $633(36)$ & $1945(116)$ & $6(38)$ & $704(66)$ & $-313(218)$ \\
\hline c(4): & $1234(3)$ & $7489(4)$ & $2562(8)$ & $150(18)$ & $428(40)$ & $1614(151)$ & $16(50)$ & $.158(86)$ & $45(144)$ \\
\hline$c(5))^{\prime}$ & $1274(3)$ & $7673(5)$ & $327(8)$ & $227(23)$ & $721(52)$ & $1240(151)$ & $68(61)$ & $-25(95)$ & $-14(161)$ \\
\hline $0(5)^{\prime}$ & $2977(2)$ & $8253(3)$ & $25(6)$ & $301(17)$ & $718(33)$ & $35 ! 3(105)$ & $-5(42)$ & $493(67)$ & $116(107)$ \\
\hline \multicolumn{10}{|c|}{ INOSINE B } \\
\hline$N(1)$ & $4685(2)$ & $6980(2)$ & $10060(6)$ & $166(17)$ & $593(39)$ & $1524(130)$ & $-124(47)$ & $294(74)$ & $-188(117)$ \\
\hline$c(2)$ & $3954(3)$ & $7344(4)$ & $10089(8)$ & $314(25)$ & $383(45)$ & $1359(155)$ & $-125(51)$ & $267(94)$ & $-94(141)$ \\
\hline$N(3)$ & $3354(2)$ & $6669(3)$ & $10177(6)$ & $180(16)$ & $363(34)$ & $1419(119)$ & $-70(37)$ & $145(69)$ & $118(106)$ \\
\hline$c(4)$ & $3555(2)$ & $5501(4)$ & $10193(7)$ & $116(19)$ & $485(44)$ & $962(134)$ & $-26(50)$ & $137(82)$ & $66(134)$ \\
\hline$c(5)$ & $4266(3)$ & $5026(4)$ & $10124(7)$ & $166(20)$ & $398(43)$ & $1121(142)$ & $-57(45)$ & $111(84)$ & $-59(127)$ \\
\hline$c(6)$ & $4922(3)$ & $5799(4)$ & $10052(8)$ & $221(23)$ & $715(54)$ & $1096(138)$ & $5(53)$ & $50(93)$ & $98(141)$ \\
\hline $0(6)$ & $\begin{array}{l}5589(2) \\
42492)\end{array}$ & $\begin{array}{l}5535(3) \\
3803(3)\end{array}$ & $\begin{array}{r}9987(6) \\
\end{array}$ & $141(13)$ & $1037(37)$ & $2381(122)$ & $-39(39)$ & $274(68)$ & $9(119)$ \\
\hline $\begin{array}{l}\mathrm{N}(7) \\
C(8)\end{array}$ & $\begin{array}{l}4249(2) \\
35293)\end{array}$ & $3803(3)$ & $10152(6)$ & $\begin{array}{l}159(17) \\
27262)\end{array}$ & $488(40)$ & $1549(124)$ & $40(40)$ & $301(73)$ & $-95(114)$ \\
\hline $\begin{array}{l}C(8) \\
N(9)\end{array}$ & $\begin{array}{l}3529(3) \\
307(2)\end{array}$ & $\begin{array}{l}3564(4) \\
4549(3)\end{array}$ & $\begin{array}{l}10227(8) \\
10256(6)\end{array}$ & $\begin{array}{l}272(26) \\
145(4)\end{array}$ & $\begin{array}{l}359(46) \\
373(34)\end{array}$ & $\begin{array}{l}1630(158) \\
1425\end{array}$ & $\begin{array}{r}-3(58) \\
-15(39)\end{array}$ & $176(97)$ & $\begin{array}{l}-241(140) \\
-153(10)\end{array}$ \\
\hline $\begin{array}{l}\text { N(9), } \\
\text { C(1). }\end{array}$ & $\begin{array}{l}3075(2) \\
2250(3)\end{array}$ & $\begin{array}{l}\begin{array}{l}4549(3) \\
4551(5)\end{array}\end{array}$ & $\begin{array}{l}10256(6) \\
10280(8)\end{array}$ & $\begin{array}{l}145(14) \\
156(19)\end{array}$ & $\begin{array}{l}373(34) \\
649(44)\end{array}$ & $\begin{array}{l}1425(121) \\
1976(170)\end{array}$ & $\begin{array}{l}-15(39) \\
-139(38)\end{array}$ & $\begin{array}{l}192(68) \\
518(93)\end{array}$ & $\begin{array}{l}-153(110) \\
-121(162)\end{array}$ \\
\hline o(1), & $2100(2)$ & $3761(3)$ & $11819(5)$ & $222(13)$ & $\begin{array}{l}4498(44) \\
778(33)\end{array}$ & $\begin{array}{l}1916(170) \\
1360(94)\end{array}$ & $\begin{array}{l}-139(48) \\
-276(36)\end{array}$ & $\begin{array}{l}518(93) \\
240(58)\end{array}$ & $\begin{array}{r}-121(162) \\
264(105)\end{array}$ \\
\hline c(2)' & $1780(3)$ & $4086(5)$ & $8352(8)$ & $190(21)$ & $501(47)$ & $1650(163)$ & $24(51)$ & $472(97)$ & $197(164)$ \\
\hline o(2): & $1657(2)$ & $4916(4)$ & $6760(6)$ & $197(15)$ & $1053(41)$ & $1989(120)$ & $17(41)$ & $404(70)$ & $982(124)$ \\
\hline$c(3) !$ & $1035(3)$ & $3749(5)$ & $9146(8)$ & $173(20)$ & $574(48)$ & $1622(160)$ & $-64(55)$ & $303(93)$ & $-63(162)$ \\
\hline $0(3) !$ & $558(2)$ & $4748(4)$ & $9255(7)$ & $180(14)$ & $832(40)$ & $2116(133)$ & $168(38)$ & $386(72)$ & $404(126)$ \\
\hline & $1323(3)$ & $3315(4)$ & $11291(8)$ & $175(21)$ & $606(43)$ & $1506(160)$ & $-89(53)$ & $286(96)$ & $-99(159)$ \\
\hline $\begin{array}{l}c(5) ! \\
0(5) !\end{array}$ & $\begin{array}{l}1330(4) \\
1606(2)\end{array}$ & $\begin{array}{l}1994(5) \\
1386(3)\end{array}$ & $\begin{array}{l}11585(11) \\
10055(6)\end{array}$ & $\begin{array}{l}260(25) \\
287(17)\end{array}$ & $\begin{array}{l}805(55) \\
696(35)\end{array}$ & $\begin{array}{l}2216(207) \\
3187(144)\end{array}$ & $\begin{array}{r}-\begin{array}{r}552(62) \\
68(41)\end{array} \\
0\end{array}$ & $\begin{array}{l}274(128) \\
187(86)\end{array}$ & $\begin{array}{r}417(195) \\
-421(127)\end{array}$ \\
\hline \multirow{2}{*}{\multicolumn{10}{|c|}{ UAIER }} \\
\hline & & & & & & & & & \\
\hline $0(10)$ & $6899(3)$ & $6524(4)$ & $3664(8)$ & $264(19)$ & $801(42)$ & $3985(172)$ & $58(48)$ & $240(98)$ & $-310(133)$ \\
\hline $0(11)$ & $\begin{array}{r}6913(3) \\
1003(3)\end{array}$ & $\begin{array}{l}5823(5) \\
5140(5)\end{array}$ & $\begin{array}{l}7987(10) \\
6006(9)\end{array}$ & $\begin{array}{l}262(19) \\
327(18)\end{array}$ & $1188(52)$ & $3087(180)$ & $\begin{array}{l}-67(47) \\
-126(66)\end{array}$ & $429(97)$ & $-649(165)$ \\
\hline $\begin{array}{l}0(12) \\
0(13)\end{array}$ & $9551(3)$ & $\begin{array}{l}5140(5) \\
5216(4)\end{array}$ & $2115(6)$ & $\begin{array}{l}327(18) \\
258(17)\end{array}$ & $\begin{array}{l}839(44) \\
780(39)\end{array}$ & $\begin{array}{l}1965(133) \\
1710(119)\end{array}$ & $\begin{array}{r}-126(46) \\
57(43)\end{array}$ & $\begin{array}{l}426(80) \\
306(79)\end{array}$ & $\begin{array}{l}264(141) \\
289(115)\end{array}$ \\
\hline
\end{tabular}

The crystal packing and hydrogen bonding

Figs. 2 and 3 show the structures of guanosine and inosine projected down the $\mathbf{c}^{*}$ direction. In spite of the extra amino group in guanosine, there are only slight differences in the crystal structures of the two compounds.

A pronounced feature of the crystal structures is the intimate parallel stacking of purine bases to form columns parallel to $\mathbf{c}$. The separation between successive purine rings within the stacks is $3 \cdot 3 \AA$. Parallel stacking of purine and pyrimidine rings is a major mode of interaction in aqueous solutions (Chan, Schweizer, Ts'o \& Helmkamp, 1964; Chan, Bangerter \& Peter, 1966; Solie \& Schellman, 1968; Ts'o \& Chan, 1964; Ts'o, Melvin \& Olsen, 1963) and is an important structural feature in the crystal structures of other nucleic acid constituents (Sundaralingam, Rao \& Bugg, 1969); however, the extent of base overlap is much greater in crystals of guanosine and inosine than in any of the previously reported crystal structures of nucleic acid constituents. Interactions between guanine derivatives in aqueous solutions are also unusually pronounced (Gellert, Lipsett \& Davies, 1962; Sarkar \& Yang, 1965; Michelson, 1958), suggesting that the intimate stacking we have observed in these crystals may also occur in solution.
The hydrogen-bonding scheme and the hydrogen bond lengths are shown in Fig. 4. The purine rings are

Table 6. Final inosine hydrogen atom parameters and their estimated standard deviations (positional parameters $\times 10^{3}$ )

\begin{tabular}{|c|c|c|c|c|}
\hline ATOM & $x$ & y & $z$ & $B\left(\AA^{2}\right)$ \\
\hline \multicolumn{5}{|c|}{ INOSINE A } \\
\hline H(1) & $216(3)$ & $710(4)$ & $637(8)$ & $3.4(1.2)$ \\
\hline $\mathrm{H}(2)$ & $238(2)$ & $913(4)$ & $374(6)$ & $1.8(.9)$ \\
\hline H(3) & $201(2)$ & $926(3)$ & $313(6)$ & $.3(.8)$ \\
\hline $\begin{array}{l}\mathrm{H}(4) \\
\mathrm{H}(5)\end{array}$ & $\begin{array}{r}80(2) \\
210(3)\end{array}$ & 691 (4) & $270(6)$ & $2.6(1.0)$ \\
\hline 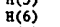 & $\begin{array}{r}210(3) \\
68(3)\end{array}$ & $\begin{array}{l}913(4) \\
896(5)\end{array}$ & $\begin{array}{l}753(7) \\
601(8)\end{array}$ & $2.1(1.4)$ \\
\hline $\mathrm{H}(7)$ & $83(3)$ & $\begin{array}{l}896(5) \\
817(4)\end{array}$ & $\begin{array}{l}601(8) \\
-28(7)\end{array}$ & $\begin{array}{l}3.3(1.4) \\
4.0(1.3)\end{array}$ \\
\hline B(8) & $119(3)$ & $688(5)$ & $-39(8)$ & $\begin{array}{l}4.0(1.3) \\
4.0(1.3)\end{array}$ \\
\hline B(9) & $239(4)$ & $777(6)$ & $28(10)$ & $7.7(2.1)$ \\
\hline $\mathrm{H}(10)$ & $361(3)$ & $895(5)$ & $486(7)$ & $3.0(1.2)$ \\
\hline B(11) & $475(3)$ & $370(4)$ & $509(8)$ & $3.9(1.2)$ \\
\hline $\mathbf{H}(12)$ & $358(2)$ & $350(4)$ & $547(6)$ & $1.5(.9)$ \\
\hline \multicolumn{5}{|c|}{ INOSINE B } \\
\hline H(1) & $213(2)$ & $540(4)$ & $1059(6)$ & $1.3(.9)$ \\
\hline $\mathrm{H}(2)$ & $200(2)$ & $335(4)$ & $800(6)$ & $2.1(1,0)$ \\
\hline (B) & $76(2)$ & $311(4)$ & $833(7)$ & $2.8(1.1)$ \\
\hline H(4) & $101(3)$ & $368(4)$ & $1220(7)$ & $3.0(1.2)$ \\
\hline $\mathrm{H}(5)$ & $207(3)$ & $509(6)$ & $633(9)$ & $5.9(1.9)$ \\
\hline $\mathrm{H}(6)$ & $41(4)$ & $509(6)$ & $823(9)$ & $5.8(2.1)$ \\
\hline $\begin{array}{l}\text { H(7 } \\
\mathrm{H}(8\end{array}$ & $\begin{array}{r}157(3) \\
75(3)\end{array}$ & $189(5)$ & $1286(9)$ & $4.4(1.6)$ \\
\hline $\begin{array}{l}H(8) \\
H(9)\end{array}$ & $\begin{array}{r}75(3) \\
215(4)\end{array}$ & $175(5)$ & $1158(8)$ & $4.8(1.3)$ \\
\hline $\begin{array}{l}\mathrm{H}(9) \\
\mathrm{H}(10)\end{array}$ & $\begin{array}{l}215(4) \\
332(2)\end{array}$ & $\begin{array}{l}116(6) \\
280(4)\end{array}$ & $1055(10)$ & $7.4(2.0)$ \\
\hline H(11) & $511(3)$ & $\begin{array}{l}280(4) \\
764(5)\end{array}$ & $\begin{array}{l}1022(6) \\
1005(9)\end{array}$ & $\begin{array}{l}.8(.9) \\
5.2(1,4)\end{array}$ \\
\hline$H(12)$ & $387(2)$ & 828(3) & $1001(6)$ & $1.6(.9)$ \\
\hline \multicolumn{5}{|l|}{ LATER } \\
\hline $\mathrm{H}(10)$ & 722 & & $319(11)$ & \\
\hline & 64 & +40 & $333(10)$ & $5.5(2.2)$ \\
\hline & 6820 & $605(8)$ & $683(13)$ & $11.3(3.6)$ \\
\hline & 69 & 5 & 843 (11) & \\
\hline & 1022 & & $600(10)$ & $8.1(2.1)$ \\
\hline & & 592 & $514(6)$ & $11.7(4.0)$ \\
\hline & $986(3$ & $505(6)$ & $113(9)$ & $6.8(1.9)$ \\
\hline $\mathrm{B}(13)^{\prime}$ & $915(3)$ & $559(5)$ & 160 (9) & $5.1(1.8)$ \\
\hline
\end{tabular}


hydrogen bonded together so as to form ribbons running in the $\mathbf{b}$ direction. In guanosine, adjacent bases are joined by two hydrogen bonds $[N(1) \ldots N(7)$ and $\mathrm{N}(2) \ldots \mathrm{O}(6)]$ while in inosine, which lacks the amino group, a single $\mathrm{N}(1) \ldots \mathrm{N}(7)$ hydrogen bond joins adjacent bases. All hydrogen atoms which are covalently bonded to oxygen or nitrogen atoms appear to participate in hydrogen bonding. Two hydrogen atoms apparently form bifurcated hydrogen bonds, for one of the amino hydrogen atoms of guanosine $B$ points approximately midway between a hydroxyl oxygen atom and a water oxygen atom, while one of the hydrogen atoms of water molecule $\mathrm{O}(11)$ is shared by two carbonyl oxygen atoms.
It is especially interesting that inosine forms the same crystal structure as guanosine in spite of the fact that it lacks the amino group which is an integral part of the hydrogen bonding scheme. This suggests that other features of the crystal structure, and primarily the parallel stacking of the purine rings, are of preponderant importance in determining the structure.

\section{Bond distances and angles}

The bond distances and angles for guanosine and inosine are shown in Figs. 5 and 6 respectively. For the most part, the bond distances and angles for nucleosides $A$ and $B$ agree well; in guanosine the root-meansquare differences between equivalent bond lengths and

Table 7. Observed and calculated structure factors for inosine

From left to right, the columns contain values of $h, 10 F_{o}, 10 F_{c}$ and $\alpha$, the phase angle fies that the integrated intensity was below background level.

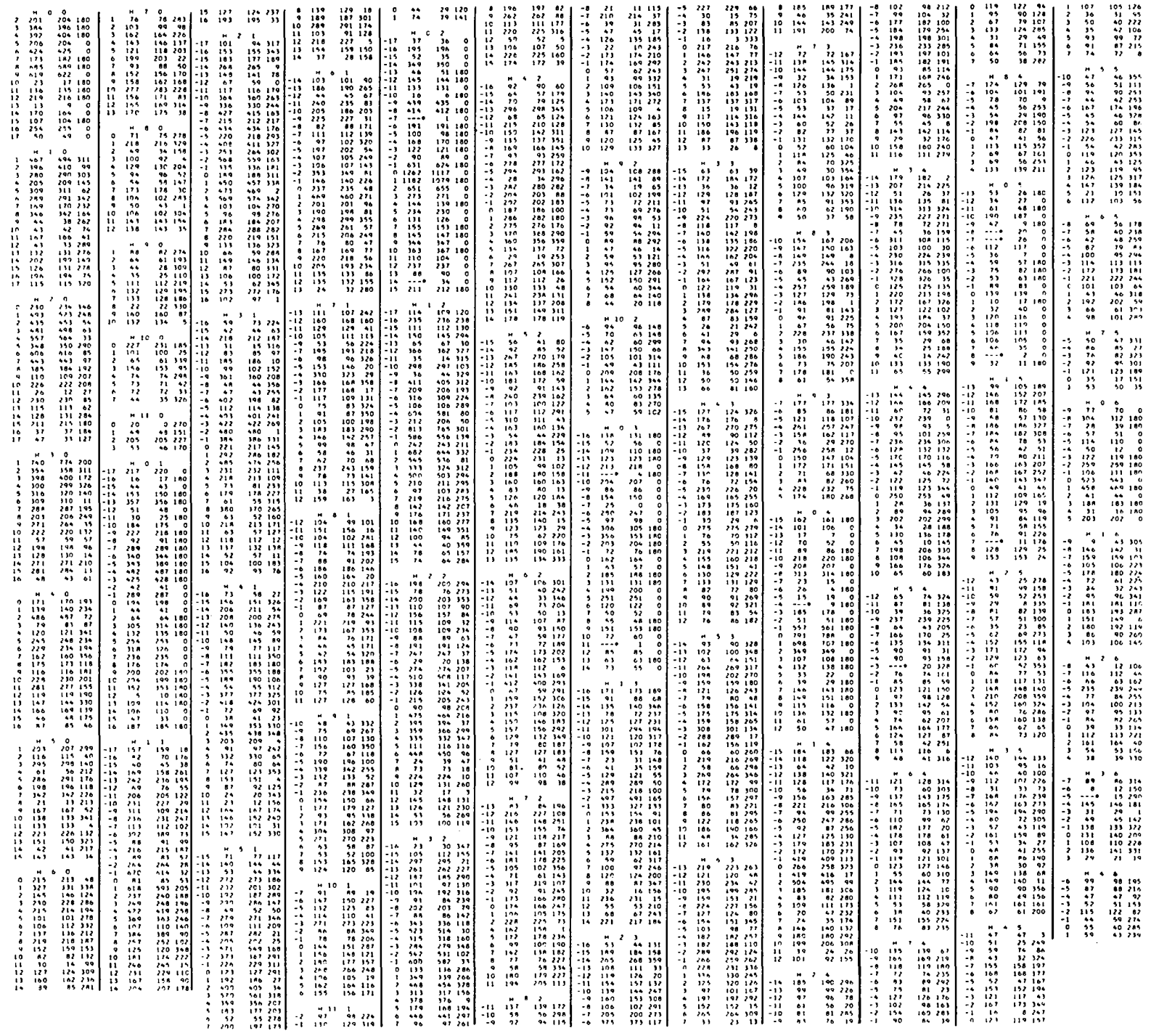




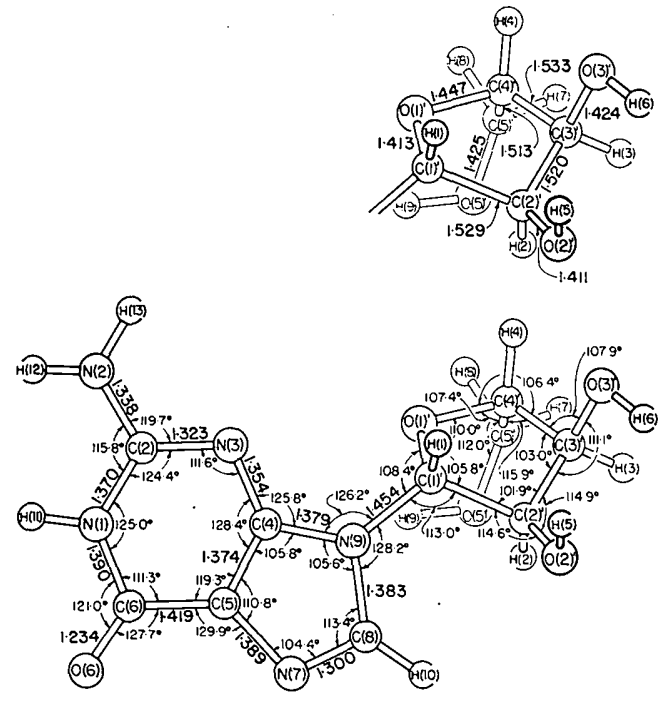

(a)

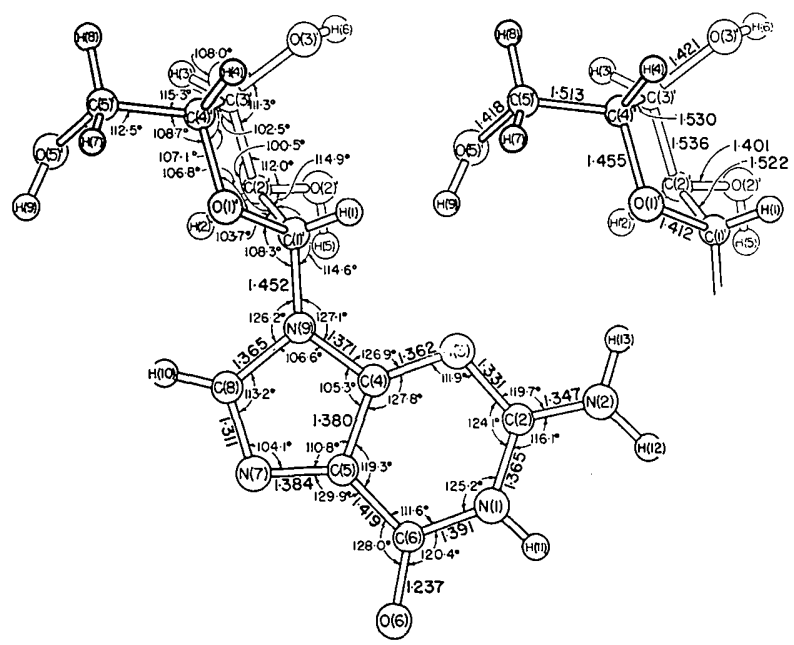

(b)

Fig. 5. The bond distances and angles involving heavy atoms in guanosine $(a)$ molecule $A ;(b)$ molecule $B$.
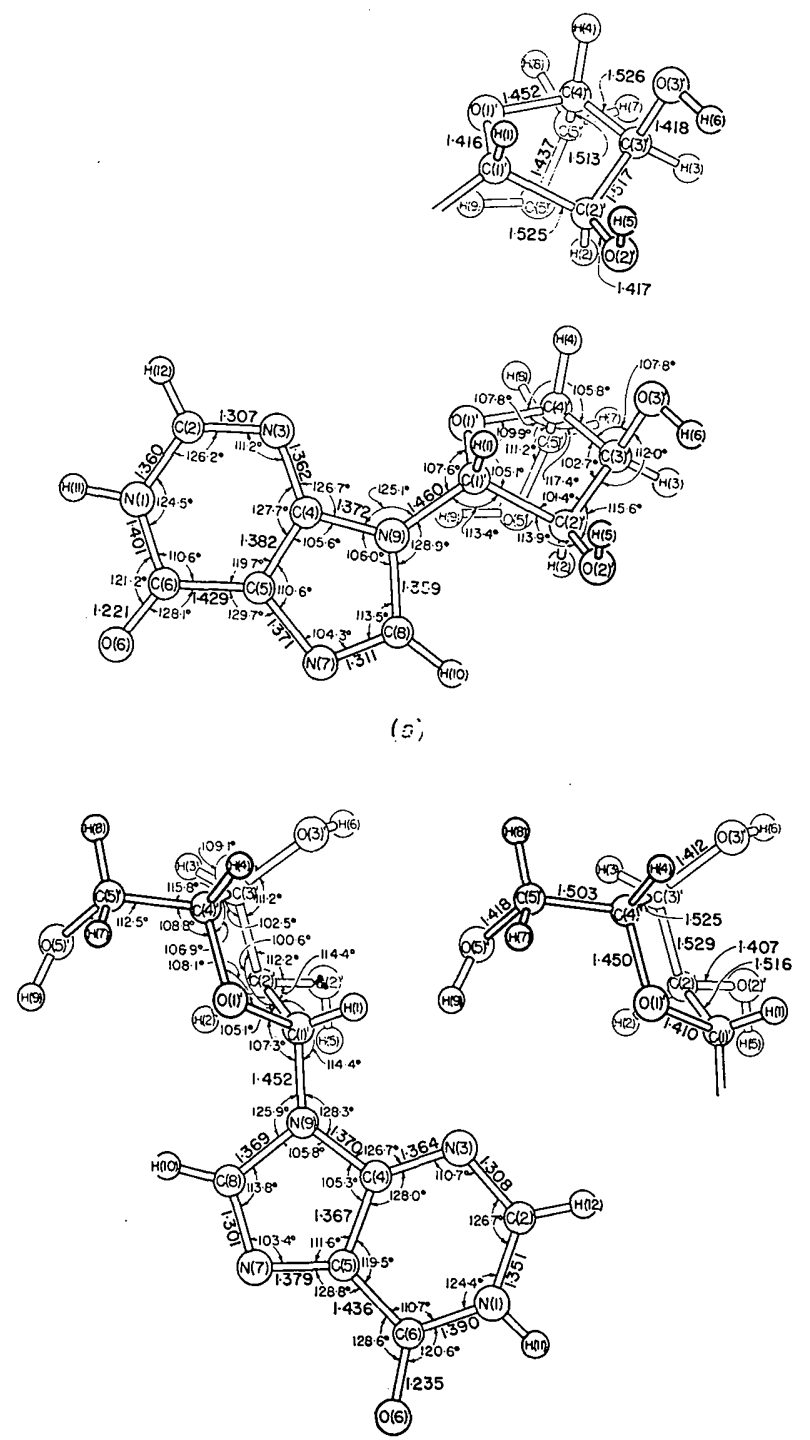

(b)

Fig.6. The bond distances and angles involving heavy atoms in inosine, $(a)$ molecule $A ;(b)$ molecule $B$.

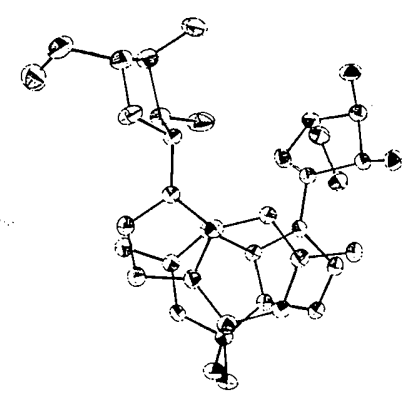

Fig. 7. A stereoscopic view of the purine stacking and the thermal motion in the guanosine structure. The atoms are represented by ellipsoids defined by the principal axes of thermal vibration. 
angles in the two nucleosides are $0.006 \AA$ and $1 \cdot 1^{\circ}$ while in the inosine structure these differences are $0.009 \AA$ and $1 \cdot 2^{\circ}$. In both structures, the largest differences between the bond lengths and angles occur in the ribose moieties and can probably be attributed to differences in the ribose conformations.

The bond distances in the purine rings of guanosine and inosine are significantly different. These differences are essentially confined to the six-membered rings and can probably be attributed to the different substituents on atom $\mathrm{C}(2)$.

Average values for the $\mathrm{C}-\mathrm{H}, \mathrm{N}-\mathrm{H}$, and $\mathrm{O}-\mathrm{H}$ distances are $0.99,0.91$, and $0.90 \AA$ in guanosine and 0.99 , 1.03 , and $0.84 \AA$ in inosine.

\section{Nucleoside conformations}

Stereoscopic views of the nucleosides are shown in Figs. 7 and 8 . Table 8 lists values for the conventional torsion angles which are routinely used to describe nucleosides and nucleotides.

The largest difference between nucleosides $A$ and $B$ is in the conformations around the glycosidic bonds. The torsion angle around this bond $(\varphi \mathrm{CN}$; see Donohue \& Trueblood, 1960; Sundaralingam \& Jensen, 1965) is $-42^{\circ}$ for nucleoside $A$ and $-123^{\circ}$ for nucleoside $B$; both are in the anti conformation. These large differences in torsion angle are consistent with a recent review (Haschemeyer \& Rich, 1967) which suggests

Table 8. Torsion angles in guanosine and inosine (see text for explanation of angles)

\begin{tabular}{lcccc}
\multicolumn{1}{c}{ Angle } & Guanosine $A$ & Guanosine $B$ & Inosine $A$ & Inosine $B$ \\
$\varphi_{\mathrm{CN}}$ & $-123 \cdot 3^{\circ}$ & $-43 \cdot 9^{\circ}$ & $-121 \cdot 2^{\circ}$ & $-47 \cdot 8^{\circ}$ \\
$\varphi_{\mathrm{OO}}$ & $50 \cdot 9$ & $73 \cdot 8$ & $55 \cdot 3$ & $73 \cdot 4$ \\
$\varphi_{\mathrm{OC}}$ & $67 \cdot 9$ & $46 \cdot 4$ & $64 \cdot 0$ & $47 \cdot 0$ \\
$\varphi \mathrm{C}\left(1^{\prime}\right) \rightarrow \mathrm{O}\left(1^{\prime}\right)$ & $-22 \cdot 1$ & $-38 \cdot 5$ & $-22 \cdot 5$ & $-31 \cdot 2$ \\
$\varphi \mathrm{C}\left(2^{\prime}\right) \rightarrow \mathrm{C}\left(1^{\prime}\right)$ & $34 \cdot 8$ & $44 \cdot 2$ & $36 \cdot 9$ & $41 \cdot 2$ \\
$\varphi \mathrm{C}(3) \rightarrow \mathrm{C}\left(2^{\prime}\right)$ & $-33 \cdot 3$ & $-32 \cdot 4$ & $-36 \cdot 6$ & $-34 \cdot 7$ \\
$\varphi \mathrm{C}\left(4^{\prime}\right) \rightarrow \mathrm{C}\left(3^{\prime}\right)$ & $21 \cdot 5$ & $11 \cdot 1$ & $24 \cdot 4$ & $17 \cdot 8$ \\
$\varphi \mathrm{O}\left(1^{\prime}\right) \rightarrow \mathrm{C}\left(4^{\prime}\right)$ & $0 \cdot 3$ & $17 \cdot 0$ & $-1 \cdot 3$ & $8 \cdot 0$
\end{tabular}

Table 9. Deviations of atoms from the best planes of the ribose rings

\begin{tabular}{lcccc} 
& \multicolumn{3}{c}{ Deviation $\AA$} \\
$\mathrm{C}\left(1^{\prime}\right)$ & Guanosine $A$ & Guanosine $B$ & Inosine $A$ & Inosine $B$ \\
$O\left(1^{\prime}\right)$ & $0.001^{*}$ & 0.609 & $-0.004^{*}$ & $0.028^{*}$ \\
$\mathrm{C}\left(2^{\prime}\right)$ & $-0.002^{*}$ & $0.044^{*}$ & $0.007^{*}$ & $0.045^{*}$ \\
$\mathrm{C}\left(3^{\prime}\right)$ & -0.548 & $-0.041^{*}$ & -0.589 & -0.605 \\
$\mathrm{C}\left(4^{\prime}\right)$ & $-0.001^{*}$ & $0.063^{*}$ & $0.004^{*}$ & $-0.026^{*}$ \\
$O\left(2^{\prime}\right)$ & $0.002^{*}$ & $-0.066^{*}$ & $-0.007^{*}$ & $0.043^{*}$ \\
$O\left(3^{\prime}\right)$ & -0.216 & 0.590 & -0.319 & -0.287 \\
$\mathrm{C}\left(5^{\prime}\right)$ & 1.346 & 1.342 & 1.353 & 1.279 \\
& -1.183 & -1.355 & -1.178 & -1.025
\end{tabular}

* Atoms included in the calculations of the least-squares planes.

The equations of the least-squares planes, with the coefficients of $X, Y$ and $Z$ equal to the direction cosines with respect to the crystallographic axes, are:

Guanosine $A:-0.5827 X-0 \cdot 5238 Y+0 \cdot 6977 Z=-4 \cdot 1897 \AA$

Guanosine $B:-0.2658 X+0 \cdot 9292 Y+0 \cdot 2916 Z=4 \cdot 8081$

Inosine $A: \quad-0.6207 X-0.4972 Y+0.6887 Z=-4.3651$

Inosine $B: \quad-0.4733 X+0.7752 Y+0.4816 Z=5.3742$
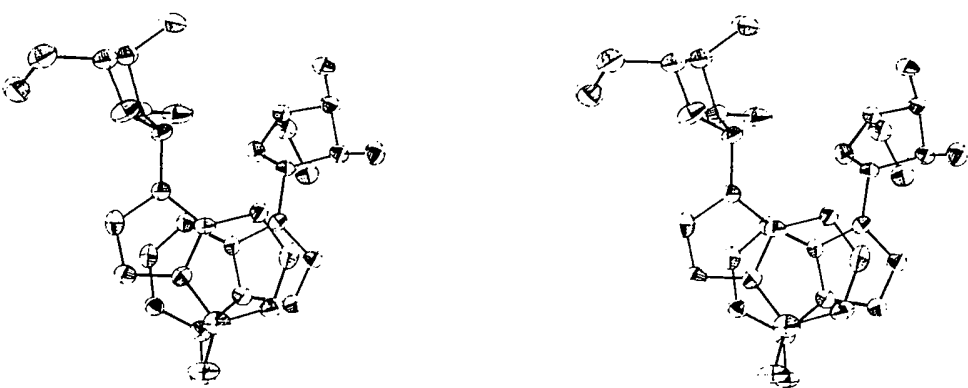

Fig. 8. A stereoscopic view of the purine stacking and the thermal motion in the inosine structure. The atoms are represented by ellipsoids defined by the principal axes of thermal vibration. 
that in purine nucleosides there is relatively little restraint to rotation about the glycosidic bond.

The conformations of the ribose rings are also considerably different in the crystallographically independent nucleosides. Table 9 lists deviations of the individual atoms from the least-squares planes through the ribose rings. In other crystal structures of nucleic acid constituents, the ribose rings have been found to pucker with four of the atoms lying in a plane and either atom $C\left(2^{\prime}\right)$ or atom $C\left(3^{\prime}\right)$ displaced from the plane of the other four atoms (Sundaralingam, 1965). Nucleoside $A$ assumes a conformation of this type with atom $C\left(2^{\prime}\right)$ displaced to the same side of the plane as atom $C\left(5^{\prime}\right)$ (the endo conformation). However, nucleoside $B$ assumes an unusual conformation with no four ring atoms forming a satisfactory plane. The ribose ring of guanosine $B$ is best described by a plane through atoms $\mathrm{O}\left(1^{\prime}\right), \mathrm{C}\left(2^{\prime}\right), \mathrm{C}\left(3^{\prime}\right)$, and $\mathrm{C}\left(4^{\prime}\right)$ with atom $\mathrm{C}\left(1^{\prime}\right)$ displaced to the opposite side of the plane from atom $C\left(5^{\prime}\right)$. The ribose of inosine $B$ is best described by a plane through atoms $\mathrm{C}\left(1^{\prime}\right), \mathrm{O}\left(1^{\prime}\right), \mathrm{C}\left(3^{\prime}\right)$, and $\mathrm{C}\left(4^{\prime}\right)$ with atom $\mathrm{C}\left(2^{\prime}\right)$ displaced to the same side of the ribose plane as atom $\mathrm{C}\left(5^{\prime}\right)($ endo).

The ribose rings can also be described in terms of torsion angles around the ring bonds (Brown \& Levy, 1963). In this notation, for example, the conformation around the $\mathrm{C}\left(1^{\prime}\right)-\mathrm{O}\left(1^{\prime}\right)$ bond is described in terms of a torsion angle $\varphi \mathrm{C}\left(1^{\prime}\right) \rightarrow \mathrm{O}\left(1^{\prime}\right)$, the angle, measured counter-clockwise, that the projection of bond $\mathrm{C}\left(1^{\prime}\right)-\mathrm{C}\left(2^{\prime}\right)$ makes relative to the projection of bond $\mathrm{O}\left(1^{\prime}\right)-\mathrm{C}\left(4^{\prime}\right)$ when one looks in the direction of the bond $\mathrm{C}\left(1^{\prime}\right)-\mathrm{O}\left(1^{\prime}\right)$. The conformation around the $\mathrm{C}\left(4^{\prime}\right)-\mathrm{C}\left(5^{\prime}\right)$ bond, described by the angles $\varphi_{0 \circ}$ and $\varphi_{\mathrm{OC}}$ (Shefter $\&$ Trueblood, 1965), is gauche-gauche for both nucleosides in the inosine and the guanosine structures.

The deviations from least-squares planes through the purine moieties of the nucleosides are listed in Table 10. As usually found for purines and pyrimidines in crystal structures, the bases in these two structures are significantly nonplanar.

\section{Thermal vibration}

Stereoscopic views of the ellipsoids of thermal vibration are shown in Figs. 1 and 8. The overall patterns of thermal anisotropy are similar in guanosine and inosine; however, the thermal motion in inosine is more pronounced than in guanosine, possibly because of the less cohesive (lower density) structure resulting from the removal of the amino groups. Vibration effects on bond lengths, which are probably small, were ignored.

\section{References}

Brown, G. M. \& Levy, H. (1963). Science, 141, 921.

BugG, C. E. \& MARSh, R. E. (1967). J. Mol. Biol. 25, 67.

BugG, C. E., Thewalt, U. \& Marsh, R. E. (1968). Biochem. Biophys. Res. Comm. 33, 436.

Chan, S. I., Bangerter, B. W. \& Peter, H. H. (1966). Proc. Nat. Acad. Sci. Wash. 55, 720.

Chan, S. I., Schwelzer, M. P., Ts'o, P. O. P. \& HelmKAMP, G. K. (1964). J. Amer. Chem. Soc. 86, 4182.

Donohue, J. \& Trueblood, K. N. (1960). J. Mol. Biol. 2, 363.

Fresco, J. R. \& Massoulí,, J. (1963). J. Amer. Chem. Soc. 85, 1352.

Gellert, M., Lipsett, M. N. \& Davies, D. R. (1962). Proc. Nat. Acad. Sci. Wash. 48, 2013.

Haschemeyer, A. E. V. \& Rich, Alexander (1967). $J$. Mol. Biol. 27, 369.

Howells, E. R., Phillips, D. C. \& Rogers, D. (1950). Acta Cryst. 3, 210.

International Tables for X-ray Crystallography (1962). Vol. III, p. 202. Birmingham: Kynoch Press.

LARSON, A. C. (1967). Acta Cryst. 23, 664.

LIPSETT, M. N. (1964). J. Biol. Chem. 239, 1250.

MicheLSON, A. M. (1958). Nature, Lond. 182, 1502.

Pochon, F. \& Michelson, A. M. (1965). Proc. nat. Acad. Sci. Wash. 53, 1425.

Radding, C. M., Josse, J. \& Kornberg, A. (1962). J. Biol. Chem. 237, 2869.

Table 10. Deviations from least-squares planes of purines plus immediate substituents

\begin{tabular}{lcccc}
\multicolumn{5}{c}{ Deviation $(\AA)$} \\
N(1) & Guanosine $A$ & Guanosine $B$ & Inosine $A$ & Inosine $B$ \\
C(2) & 0.008 & 0.018 & -0.009 & 0.008 \\
N(2) & 0.009 & 0.007 & -0.001 & -0.009 \\
N(3) & -0.032 & -0.035 & - & - \\
C(4) & 0.035 & 0.019 & 0.037 & 0.005 \\
C(5) & 0.028 & 0.020 & 0.023 & 0.011 \\
C(6) & 0.028 & 0.008 & 0.030 & -0.001 \\
O(6) & 0.001 & 0.005 & -0.010 & -0.001 \\
N(7) & -0.035 & -0.014 & -0.042 & -0.010 \\
C(8) & 0.011 & -0.013 & 0.023 & -0.001 \\
N(9) & -0.012 & -0.013 & 0.012 & 0.004 \\
C(1) & -0.010 & 0.018 & -0.002 & 0.012 \\
& -0.031 & -0.020 & -0.061 & -0.018
\end{tabular}

The equations of the least-squares planes with the coefficients of $X, Y$ and $Z$ equal to the direction cosines with respect to the crystallographic axes, are:

Guanosine $A: 0 \cdot 0270 X+0 \cdot 0258 Y+0 \cdot 9853 Z=3 \cdot 7285 \AA$

Guanosine $B: 0.0265 X+0.0221 Y+0.9854 Z=6.9984$

Inosine $A: \quad 0.0533 X+0.0577 Y+0.9790 Z=4.0891$

Inosine $B: \quad 0.0319 X+0.0124 Y+0.9845 Z=6.9433$ 
Ralph, R. K., Connors, W. J., Schaller, H. \& Khorana, H. G. (1963). J. Amer. Chem. Soc. 85, 1983.

SARKAR, P. K. \& YANG, J. T. (1965). Biochem. Biophys. Res. Comm. 20, 346.

Shefter, E. \& Trueblood, K. N. (1965). Acta Cryst. 18, 1067.

Solie, T. N. \& Schellman, J. A. (1968). J. Mol. Biol. 33, 61. Stewart, R. F., Davidson, E. R. \& Simpson, W. T. (1965). J. Chem. Phys. 42, 3175.
Sundaralingam, M. (1965). J. Amer. Chem. Soc. 87, 599. Sundaralingam, M. \& Jensen, L. H. (1965). J. Mol. Biol. 13, 914.

Sundaralingam, M., RaO, S. T. \& Bugg, C. E. (1969). Abstr. Amer. Cryst. Assoc. Meeting, Seattle, Wasington, L5.

Ts'o, P. O. P. \& Chan, S. I. (1964). J. Amer. Chem. Soc. 86, 4176.

Ts'o, P. O. P., Melvin, I. S. \& Olsen, A. C. (1963). J. Amer. Chem. Soc. 85, 1289.

Acta Cryst. (1970). B26, 1101

\title{
The Crystal and Molecular Structure of Inosine
}

\author{
By A.R.I. MunNS AND P. Tollin \\ Carnegie Laboratory of Physics, The University of Dundee, Dundee, Scotland
}

(Received 14 July 1969)

\begin{abstract}
The structure of inosine $\left(\mathrm{C}_{10} \mathrm{~N}_{4} \mathrm{O}_{5} \mathrm{H}_{12}\right)$ which crystallizes in the space group $P 2_{1}$ with one molecule per asymmetric unit and with unit-cell dimensions: $a=4 \cdot 818 \pm 0 \cdot 005, b=10 \cdot 45 \pm 0 \cdot 01, c=10 \cdot 97 \pm 0 \cdot 01 \AA$ and $\beta=90^{\circ} 43^{\prime} \pm 2^{\prime}$, has been determined from X-ray intensity data collected from linear and four-circle diffractometers. The structure was solved by a Patterson function interpretation method and the positional and thermal parameters were refined by the method of least squares, using anisotropic thermal parameters for the non-hydrogen atoms. The final $R$ value for the 1298 observed reflexions was 0.046 and the standard deviations in the bond lengths and angles are about $0.004 \AA$ and $0.3^{\circ}$ respectively. The purine ring in inosine is planar, but both $\mathrm{O}(10)$ and $\mathrm{C}\left(1^{\prime}\right)$ are significantly displaced from this plane. The dihedral angle between the base and sugar planes is $71.0^{\circ}$ and the glycosidic torsion angle, $\varphi_{\mathrm{CN}}$ is $-10.6^{\circ}$. Atom $C\left(3^{\prime}\right)$ of the ribose ring is displaced by $0.63 \AA$ from the plane of the remaining ring atoms and is in the endo conformation. The orientation of the $\mathrm{C}\left(5^{\prime}\right)-\mathrm{O}\left(5^{\prime}\right)$ bond is gauche to $\mathrm{C}\left(4^{\prime}\right)-\mathrm{O}\left(1^{\prime}\right)$ and trans to $C\left(4^{\prime}\right)-C\left(3^{\prime}\right)$, the $\varphi_{\mathrm{OO}}$ and $\varphi_{\mathrm{OC}}$ angles being $74 \cdot 7$ and $169 \cdot 0^{\circ}$ respectively. All available groups participate in the hydrogen bonding. There is in addition one particularly short $\mathrm{C}-\mathrm{O}$ distance involving a hydrogen atom.
\end{abstract}

\section{Introduction}

The determination of the structure of inosine was undertaken as part of a series of structure determinations of nucleic acid components in progress in this laboratory. Inosine is a nucleoside which occurs occasionally in ribonucleic acid (RNA), particularly in molecules of transfer RNA. In transfer RNA inosine appears to form part of a number of anticodons and it has been suggested (Crick, 1966; Woese, 1967) that it is important because it can form a base pair with any of the bases, adenine, uracil or cytidine. Accurate structural information may help towards an understanding of the function of inosine in the anticodon and may be useful if model-building is required for the solution of the structure of crystalline transfer RNA. The determination of this structure provided an opportunity to test the usefulness of incorporating the rotation function of Rossmann \& Blow (1962) into the Patterson function interpretation procedure in use in this laboratory. A preliminary account of this work has been given (Tollin \& Munns, 1969).

\section{Experimental}

Crystals of inosine $\left(\mathrm{C}_{10} \mathrm{~N}_{4} \mathrm{O}_{5} \mathrm{H}_{12}\right)$, whose structural formula appears in Fig. 1 along with the numbering system used in this paper, were obtained by evaporation from aqueous solutions. Three distinct crystal forms were obtained depending on the rate of evaporation and the temperature at which it took place. The first form, obtained by fast evaporation at $20^{\circ} \mathrm{C}$, consisted of colourless needles showing apparent orthorhombic symmetry and cell dimensions $a=$ $8 \cdot 16 \pm 0 \cdot 04, b=13 \cdot 3 \pm 0 \cdot 2, c=21 \cdot 4 \pm 0 \cdot 2 \AA$. However, these crystals showed a marked tendency to form twinned crystals and were not investigated further. Slow evaporation from partially sealed test tubes at $19^{\circ} \mathrm{C}$ produced needle crystals of monoclinic symmetry with cell dimensions $a=6 \cdot 68 \pm 0 \cdot 05, b=11 \cdot 3 \pm 0 \cdot 1, c=$ $17 \cdot 4 \pm 0 \cdot 1 \AA, \beta=98 \cdot 3 \pm 0 \cdot 1^{\circ}$, belonging to the space group $P 2_{1}$. This structure has been determined by Bugg, Thewalt \& Marsh (1968) and independently in this laboratory. A comparison of the results of the two structure determinations is in preparation (Munns, Tollin, Wilson \& Young, 1970). 